\title{
Biogeography, diversity and environmental relationships of shelf and deep-sea benthic Amphipoda around Iceland
}

\author{
Anne-Nina Loerz ${ }^{\text {Corresp., } 1}$, Stefanie Kaiser ${ }^{2}$, Jens Oldeland ${ }^{3}$, Caroline Stolter $^{4}$, Karlotta Kürzel ${ }^{5}$, Saskia Brix ${ }^{6}$ \\ 1 Institute for Marine Ecosystems and Fisheries Science, Universität Hamburg, Hamburg, Germany \\ ${ }^{2}$ Faculty of Biology and Environmental Protection, Department of Invertebrate Zoology and Hydrobiology, University of Łódź, Lodz, Poland \\ 3 Eco-Systems, Hamburg, Germany \\ 4 Department Biology, Zoological Institute, Universität Hamburg, Hamburg, Germany \\ 5 Department Biology, Universität Hamburg, Hamburg, Germany \\ 6 Deutsches Zentrum für Marine Biodiversität, Senckenberg Nature Research Society, Hamburg, Germany \\ Corresponding Author: Anne-Nina Loerz \\ Email address: Anne-Nina.Loerz@uni-hamburg.de
}

The waters around Iceland, bounding the Northern North Atlantic and the Nordic seas, are a region characterized by complex hydrography and seabed topography. This and the presence of the Greenland-Iceland-Faroe-Scotland ridge (GIFR) are likely to have a major impact on the diversity and distribution of the benthic fauna. Biodiversity in this region is also under increasing threat from climate-induced changes, ocean warming and acidification in particular, affecting the marine realm. The aim of the present study was to investigate the biodiversity and distributional patterns of amphipod crustaceans in Icelandic waters and how it relates to environmental variables and depth. A comprehensive data set from the literature and recent expeditions was compiled constituting distributional records for 355 amphipod species across a major depth gradient (18-3700 m). Using a $1^{\circ}$ hexagonal grid to map amphipod distributions and a set of environmental factors (depth, $\mathrm{pH}$, phytobiomass, velocity, dissolved oxygen, dissolved iron, salinity and temperature) we could identify four distinct amphipod assemblages: A Deep-North, Deep-South, and a Coastal cluster as well as one restricted to the GIFR. In addition to depth, salinity and temperature were the main parameters that determined the distribution of amphipods. Diversity differed greatly between the depth clusters and was significantly higher in coastal and GIFR assemblages compared to the deep-sea clusters north and south of the GIFR. A variety of factors and processes are likely to be responsible for the perceived biodiversity patterns, which, however, appear to vary according to region and depth. Low diversity of amphipod communities in the Nordic basins can be interpreted as a reflection of the prevailing harsh environmental conditions in combination with a barrier effect of the GIFR. By contrast, low diversity of the deep North Atlantic assemblages might be linked to the variable nature of the oceanographic environment in Peer) reviewing PDF Y(2021:03:59448:2:0:NEW 7 Jul 2021) 
the region over multiple spatio-temporal scales. Overall, our study highlights the importance of amphipods as a constituent part of Icelandic benthos. The strong responses of amphipod communities to certain water mass variables raise the question of whether and how their distribution will change due to climate alteration, which should be a focus of future studies. 


\section{Biogeography, diversity and environmental}

2 relationships of shelf and deep-sea benthic

3 Amphipoda around Iceland

4

5

6

7

8

9

10

11

12

13

14

15

16

17

19

20

21

22

23

24

25

26

27

28

29

30

31

32

33

34

35

36

37
Anne-Nina Lörz ${ }^{1}$, Stefanie Kaiser ${ }^{2}$, Jens Oldeland ${ }^{3}$, Caroline Stolter ${ }^{4}$, Karlotta Kürzel ${ }^{1}$, Saskia Brix $^{5}$

${ }^{1}$ Universität Hamburg, Germany

${ }^{2}$ University of Łódź, Poland

${ }^{3}$ Eco-Systems, Hamburg, Germany

${ }^{4}$ Universität Hamburg, Germany

${ }^{5}$ Senckenberg am Meer, Hamburg, Germany

Corresponding Author:

Anne-Nina Lörz ${ }^{1}$

Institute for Marine Ecosystem and Fisheries Science, Universität Hamburg, Germany

Email address: Anne-Nina.loerz@uni-hamburg.de

\section{Abstract}

The waters around Iceland, bounding the Northern North Atlantic and the Nordic seas, are a region characterized by complex hydrography and seabed topography. This and the presence of the Greenland-Iceland-Faroe-Scotland ridge (GIFR) are likely to have a major impact on the diversity and distribution of the benthic fauna. Biodiversity in this region is also under increasing 
39 threat from climate-induced changes, ocean warming and acidification in particular, affecting the

40

41

42

43

44

45

46

47

48

49

50

51

52

53

54

55

56

57

58

59

60

61

62

63

64

65

66

67

68

69

70

marine realm. The aim of the present study was to investigate the biodiversity and distributional patterns of amphipod crustaceans in Icelandic waters and how it relates to environmental variables and depth.

A comprehensive data set from the literature and recent expeditions was compiled constituting distributional records for 355 amphipod species across a major depth gradient (18-3700 m). Using a $1^{\circ}$ hexagonal grid to map amphipod distributions and a set of environmental factors (depth, $\mathrm{pH}$, phytobiomass, velocity, dissolved oxygen, dissolved iron, salinity and temperature) we could identify four distinct amphipod assemblages: A Deep-North, Deep-South, and a Coastal cluster as well as one restricted to the GIFR. In addition to depth, salinity and temperature were the main parameters that determined the distribution of amphipods. Diversity differed greatly between the depth clusters and was significantly higher in coastal and GIFR assemblages compared to the deep-sea clusters north and south of the GIFR.

A variety of factors and processes are likely to be responsible for the perceived biodiversity patterns, which, however, appear to vary according to region and depth. Low diversity of amphipod communities in the Nordic basins can be interpreted as a reflection of the prevailing harsh environmental conditions in combination with a barrier effect of the GIFR. By contrast, low diversity of the deep North Atlantic assemblages might be linked to the variable nature of the oceanographic environment in the region over multiple spatio-temporal scales. Overall, our study highlights the importance of amphipods as a constituent part of Icelandic benthos. The strong responses of amphipod communities to certain water mass variables raise the question of whether and how their distribution will change due to climate alteration, which should be a focus of future studies.

2

\section{Introduction}

Human impacts on the world's oceans are fundamentally altering the biogeography and biodiversity of marine communities (Lotze et al., 2006; Halpern et al., 2008). Cumulating effects of climate change, resource exploitation and pollution are particularly pronounced in the Northern Hemisphere, and some of these changes have already evoked significant biotic 
71 responses, such as shifts in distribution and abundance (e.g., Harley et al., 2006; Jones et al., 72 2014; Birchenough et al., 2015; Hiddink et al., 2015). The pace and strength of global warming 73 and increased atmospheric $\mathrm{CO}_{2}$ may be faster and greater in the ocean than in the terrestrial 74 realm (Burrow et al., 2011), but our knowledge of the consequences for the marine biota is 75 limited (Richardson \& Poloczanska, 2008). Uncovering distribution patterns of species and the 76 identification of the ecological and evolutionary factors and processes responsible for them is 77 therefore vital for predicting biodiversity responses to global change.

78 A complex array of mechanisms have been identified to determine the distribution of species on 79 multiple spatial and temporal scales (Leibold et al., 2004). Abiotic variables confine the space 80 that species occupy according to their physiological limits (Chase \& Leibold, 2003). Species' 81 dispersal capacity alongside their evolutionary heritage defines the size of their realized 82 distribution (Grantham et al., 2003; Hilário et al., 2015; Baco et al., 2016). Finally, biological 83 relationships are known to structure spatial patterns of species in many ways, such as those 84 associated with competitors, consumers, and facilitators (Jablonski, 2008; Bascompte, 2009). 85 86 Environmental differences may be less obvious in the deep sea $(>200 \mathrm{~m})$ than in the shallows. It is now clear, though, that there is considerable spatial and temporal variation in the physical and 87 biological properties to which species are exposed and which determine their distribution.

88 Processes associated with sediment properties, temperature, salinity, nutrient input and dissolved 89 oxygen are among the main drivers for structuring biodiversity and its geographical distribution

90 (Levin et al., 2001; Schnurr et al., 2018). However, there is still a lack of understanding of 91 distribution boundaries in the marine realm and even less so in the deep sea (Lourie \& Vincent, 92 2004; Rex et al., 2005), making it difficult to predict how communities will respond in the wake 93 of a changing ocean.

94 The waters around Iceland and adjoining seas represent a spatially heterogeneous environment 95 with steep gradients that promote distinct habitats and related communities. As a boundary 96 region between temperate North Atlantic, and polar waters, they are also considered to be very susceptible to climatic changes (Astthorsson et al., 2007; Eiríksson et al., 2011). Iceland is located on top of the mid-Atlantic ridge and is criss-crossed by several topographic barriers that determine the flow of water masses and ultimately the distribution of species. At the forefront is the Greenland-Iceland-Faroe ridge (GIFR), which stretches from Scotland and the Faroes via Iceland to Greenland, and and restricts the exchange of water masses between the warm, salty 
102 North Atlantic waters and the cold and less salty Nordic Seas (Hansen et al., 2008). As a result, 103 seabed temperature and salinity differ strongly between areas north and south of the GIFR, 104 which, in turn, can lead to marked differences in species compositions (Weisshappel \& 105 Svavarsson, 1998; Weisshappel, 2000; Bett, 2001; Weisshappel, 2001, Brix \& Svavarsson, 2010; 106 Dauvin et al., 2012; Jochumsen et al., 2016; Schnurr et al., 2018). Alterations of the 107 physicochemical environment, including temperature rise, ocean acidification, and salinity, have 108 already been observed around Iceland (Astthorsson et al., 2007; Olafsson et al., 2009; Seidov et 109 al., 2015; Jochumsen et al., 2016). Knowledge on the most important environmental parameters 110 structuring

111 deep-sea benthic communities would therefore allow prediction of future changes for those 112 communities.

113 Amphipod crustaceans are very common and diverse across marine benthic habitats (Just, 1980;

114 De Broyer \& Jazdzewski, 1996; Lörz, 2010; Stransky \& Brandt, 2010; Brix et al., 2018;

115 Jażdżewska et al., 2018), and also in Icelandic waters (Weisshappel 2000; Weisshappel, 2001;

116 Dauvin et al., 2012; Brix et al., 2018). Their occurrence in a wide variety of marine

117 environments, in turn translates into a diverse feeding types that comprise detritivores, 118 suspension-feeders, predators, and scavengers amongst others (Guerra-García et al., 2014). But 119 they also play a central role in the marine food web (e.g., Lörz, 2010; Nyssen et al., 2002). 120 Amphipods, as a member of the crustacean superorder Peracarida, have a brooding life style, 121 from which a limited dispersal capacity is derived for most species making them potentially very 122 susceptible to environmental change (e.g., Jablonsky \& Roy, 2003; but see Lucey et al., 2015). 123 Exceptions are purely pelagic species (e.g., within the Hyperiidea) or species of the highly 124 mobile scavenging guild.

125 The aim of this study was to identify the main factors influencing the distribution and 126 biodiversity of marine amphipods in the waters around Iceland. This could provide hints as to 127 which variables could most importantly affect distribution changes as a result of climate change.

128 For this purpose, a comprehensive data--set from the literature and recent expeditions was 129 compiled constituting distributional records for 355 species across a major depth gradient (18$1303700 \mathrm{~m}$ ). These come from historical missions, in particular the Danish Ingolf expedition (1895 131 and 1896), which carried out sampling in Icelandic and West Greenlandic waters (Stephensen 132 1944b), but mainly from sampling as part of BIOICE (Benthic Invertebrates of Icelandic Waters) 
133 and IceAGE (Icelandic marine Animals: Genetics and Ecology) projects (e.g,, Brix et al. 2014).

134 Earlier community analyses of the Icelandic amphipod fauna identified depth as a strong driver 135 of species distributions, but water mass properties were also important (Dauvin et al., 2012; Brix 136 et al., 2018). In this regard, the GIFR appears to act as a major, albeit surmountable distributional 137 barrier (Weisshappel \& Svavarsson, 1998; Weisshappel, 2000; Weisshappel, 2001; Dauvin et al., 138 2012; Brix et al., 2018). Therefore, we tested whether geographical distinctions of Iceland, 139 mainly determined by the GIFR and depth, are mirrored by the distribution of benthic 140 amphipods.

141

\section{Materials \& Methods}

\section{Amphipoda data}

144 We compiled data on occurrences and abundance of 355 amphipod species for 532 localities from 145 the literature. The following expeditions and respective data sources were used: extensive literature 146 search, data from BIOICE and IceAGE expeditions. The assembled dataset was highly 147 heterogenous regarding sampling effort and method, time, location and date of the different 148 expeditions. Many only listed one or two species, in particular the historic data from e.g. Boeck 149 (1861), Hansen (1887) and Stephensen (1933, 1938, 1942, 1944a, b) only providing occurrence 150 data. However, other had high abundances of individuals (max: 2709) and high species richness 151 (max: 72). Due to this high heterogeneity, we aggregated the data at a coarser spatial resolution.

A common approach is to construct a coarse rectangular grid in which species occurrences are joined. We constructed a hexagonal grid using QGIS (QGIS Development Team, 2019) with a horizontal diameter of $1^{\circ}$ per grid cell. Within each grid cell, the occurrence and abundance information were pooled, so that a grid cell contained information from multiple localities but species were not double counted, yet the sum of the abundances per species could be calculated. Hexagonal grids have several advantages over rectangular grids, e.g. symmetric neighbourhood relations or reduced edge effects (Birch et al., 2007). For our study the most compelling reason to favour a hexagonal grid was the match of the polygons to the coastlines of Iceland and Greenland. Hexagonal grids provided a much better fit to this jagged pattern with an appropriate size, whereas 
162 of our sampling. Given the case that many of our samples were near the coast, the hexagonal design 163 clearly improved our sampling design.

\section{Environmental layers}

165 We extracted twelve variables from the Bio-Oracle 2.0 database (Assis et al., 2018) using the 166 sdmpredictors package (Bosch, 2018). Variables were chosen to represent major environmental 167 deep-sea gradients (Table 1). All variables, except minimum depth, represented long-term 168 maximum values modelled at minimum depths on a raster with $7 \mathrm{~km}^{2}$ resolution per cell. In order 169 to use the parameters on the same spatial scale as the species data, we aggregated the raster data 170 to the scale of the hexagonal grid cells by calculating the mean raster value for each grid cell. 171 Hexagons then represented the summed species abundances and averaged environmental data.

172 We analysed the environmental data for multicollinearity on the level of the hexagons. We 173 calculated a Pearson correlation matrix (AppS1) for all environmental layers and removed all 174 layers with a Pearson's $r$ above 0.75. As expected, we found strong correlation between parameters 175 of the same information type, i.e. Chl- $a$ and primary productivity or all nutrient related parameters. 176 Finally, we retained the following parameters: depth, $\mathrm{pH}$, phytobiomass, velocity, dissolved 177 oxygen, dissolved iron, salinity and temperature. We kept salinity although it was correlated with 178 temperature as it is one of the most important parameters structuring deep-sea communities around 179 Iceland (e.g., Weisshappel \& Svavarsson, 1998)

180

181

\section{Environmental Cluster Analysis}

182 We hypothesized that deep-sea regions with similar environmental conditions would have a similar 183 benthic fauna. Hence, we clustered the hexagonal grid cells based on the reduced set of the 184 averaged environmental layers into a small set of environmentally homogenous regions. We used 185 the mclust package (Scrucca et al., 2016) to conduct model-based hierarchical clustering using 186 finite Gaussian Mixtures. The clustering algorithm compares 14 differently shaped types of 187 Gaussian covariance structures representing different kinds of elliptical shapes ordered by an 188 increasing complexity. The different models are compared using the Bayesian Information 189 Criterion (Burnham \& Anderson, 2002) choosing the model with the lowest complexity. Based on 190 the plot of the different BIC models for possible cluster sizes from 2 to 10 (S3), we identified the 
191 optimal cluster as that one with highest regionalization capacity, i.e. having a low number of 192 clusters but already touching the plateau of the curve, signalling little differences in the model fit. 193 We further confirmed the optimal number of clusters using a bootstrapped sequential likelihood 194 ratio test (Scrucca et al., 2016) by comparing an increasing number of cluster sizes. Finally, we 195 calculated mean, standard deviation, minimum and maxima for each parameter and cluster 196 combination. This was done to allow an interpretation of the environmental conditions 197 representing the clusters.

\section{Taxonomic data}

200 To interpret the overlap between clusters in terms of species composition, we first performed a 201 constrained analysis of principal coordinates (CAP) (Anderson \& Willis, 2003) with presence

202

203

204

205

206

207

208

209

210

211

212

213

214

215

216

217

218

219

220 absence information and the Jaccard distance measure. CAP is an ordination technique, that allows to visualize similarities in sites based on species composition and environmental correlates. The ordination diagram was visually inspected by plotting the sites encircled by hulls on the first two axes. We further calculated the ANOSIM statistic on presence/absence transformed species data. ANOSIM is a non-parametric method to measure the community-wise overlap between different clusters (Clarke, 1993). It yields a statistic called $R$ that is in the range from 0 to 1 with values of $\mathrm{R}$ below 0.5 indicating strong overlap. The statistic is tested for significance using a permuted $\mathrm{p}$ value ( $\mathrm{n}=9999)$. $\mathrm{R}$-values above 0.75 indicate largely non-overlapping clusters with strongly different species composition. Both analyses were performed using the vegan package (Oksanen et al., 2019).

To identify characteristic species for each cluster, we identified all species being positively associated with one specific cluster or combinations of clusters using the multipatt function of the indicspecies package (Cáceres \& Legendre, 2009). We used the group-size corrected Indicator Value (IndVal.g) as a measure of association. The null hypothesis tested is that the association of a species is not higher in a specific cluster than in the other clusters. This function calculates a pvalue based on 9999 permutations, which is not corrected for multiple testing. However, as we are not interested in the number of indicator species, but in whether a species has a high association to a cluster or not, the p-values do not have to be adjusted (De Cáceres et al., 2010). After the analysis, species with high association values were extracted as lists for each cluster combination. 
221 The resulting species-cluster relationship was compared with literature and information from the

222 World Register of Marine Species (WoRMS) database (Horton et al., 2021).

223

224

Diversity

225 We aimed to compare amphipod diversity between the different clusters. However, due to different 226 numbers of samples $(n=136)$, i.e. hexagonal cells, that contained the species data, clusters were 227 not directly comparable in terms of diversity. Hence, we conducted a combined rarefaction228 extrapolation analysis based on Hill numbers (Chao et al., 2014). The concept of comparing 229 species diversity using Hill numbers stems from the fact that most diversity indices are measures 230 of entropy, such as Shannon or Simpson and do not translate directly into a diversity measure 231 although often applied in such a way (Jost, 2006). Yet three well known measures of diversity i.e. species richness, Shannon and Simpson diversity (Shannon \& Weaver, 1949, Simpson, 1949) can be generalized by a formula derived by Hill (Jost, 2006; Chao et al., 2014) which orders the indices along an order of q, i.e. $\mathrm{q}=0,1,2$ translating to richness, Shannon and Simpson, respectively. This order reflects an increasing importance of the evenness component of diversity, while the richness component becomes less effective. This means that for richness, there is no effect of abundance on the diversity measure, while for the Simpson index, rare species only have little effect on the estimated diversity values. Hence, the Simpson index is often thought to be the most robust index, when number of individuals strongly differ, as is the case here. The diversity information is transformed into a common measure of diversity, the effective number of species, which is the number of species having equal abundances that would be required to reach e.g. the Shannon entropy value of the sample. This measure allows comparisons of all three different indices having the same unit, the effective number of species. We performed the analysis using the iNEXT package (Hsieh et al., 2016) based on the summed abundance vectors per species and cluster.

When studying deep-sea organisms, the most important indirect environmental gradient is depth in meters. In order to evaluate the diversity pattern related to depth we studied the original data from the different stations $(n=536)$ and expeditions. First, we calculated a Poisson Generalized

248 Linear Model (GLM) to quantify the relationshop between the number of species per station and depth in meters. Then we split the depth gradient in 100-m intervals to study the trend of the maximum number of species across the depth gradient. 


\section{Results}

252 General

253 The total number of amphipod individuals analyzed is $n=71108$. The assembled dataset contained 254355 species from 141 genera and 44 families (Tab. 2). From these, 101 species were only be 255 identified to the genus level, where species were given a numerical code. The original number of 256 stations from the expeditions $(\mathrm{n}=532)$ were reduced to a set of 136 one-degree wide hexagonal 257 cells in order to reduce the heterogeneity in the dataset. These hexagonal cells were clustered 258 according to their environmental conditions. The entire dataset is available via Peer J supplement 259 as well as Pangaea (GfBIO) https://doi.org/10.1594/PANGAEA.931959 (Lörz et al., 2021).

260

\section{Environmental clusters}

262 The mclust algorithm identified six clusters to be the optimal configuration according to BIC and 263 the likelihood ratio tests. However, when aggregating the species data to six clusters, this would 264 result in clusters with disproportionally large differences in samples per cluster. Hence, we reduced 265 the final number of clusters to four (Fig.1). As the clustering is hierarchical, and the four-cluster 266 solution is not much worse in terms of BIC we were confident that this aggregation is more 267 informative with regard to the species than the six-cluster solution which would have split the 268 northern and southern clusters into separate regions for the specific basins (the six cluster map is shown in the supplementary data). The four-cluster solution also provides a good overview of the large-scale spatial pattern. There is a "Coastal" cluster ( $n=34$ cells) which is always close to the coastline and is characterized by shallow depth, high amounts of dissolved iron and phytobiomass

272 and warm, oxygen-rich waters with a high current speed (Fig 2). The second cluster resembles the 273 GIFR ( $\mathrm{n}=55$ ), which spreads from west to east and separates the northern and southern basis. In 274 many points it is similar to the coastal cluster but is deeper and with less dissolved iron, oxygen, 275 and phytobiomass. The other two clusters are called "Deep South" (n=19) and "Deep North" $276 \quad(n=28)$ as they represent the deep-sea regions around Iceland. They differ strongly from the first 277 two clusters by having very low values for many parameters. "Deep North" differs from "Deep 278 South" by being much colder, with almost no current velocity. Further, "Deep North" has a much 279 higher amount of dissolved oxygen and $\mathrm{pH}$. The lowest depths of around $3400 \mathrm{~m}$ are observed in 280 the Aegir ridge. These four clusters thus characterize the environmental conditions around Iceland 281 on a regional spatial scale. 
282

\section{Constrained ordination}

284 We conducted a constrained ordination to verify the amount of variation explained in the species 285 data by the environmental information contained at the level of the hexagonal cells. The 286 constrained axes of the ordination explained $11 \%$ of the total variation, while $89 \%$ is explained by 287 the 357 unconstrained axes. According to a permutation test of the marginal effects of each 288 environmental variable carried out using the anova.cca function of the vegan package, the most 289 important environmental variables were temperature $(\mathrm{F}=2.34, \mathrm{p}<0.001)$, depth $(\mathrm{F}=2.123, \mathrm{p}<$ 290 0.001), and salinity $(\mathrm{F}=2.01, \mathrm{p}<0.001)$.

291 The four different clusters strongly overlapped in ordination space (Fig. 3a). The ANOSIM-R 292 value of 0.197 signals considerable similarity in species composition between the clusters. All 293 clusters overlap in the centre of the diagram; their large spread indicates strong heterogeneity. The 294 deep-sea clusters overlapped less than the coastal and GIFR-cluster. In general, the first 295 constrained axis represented the depth gradient, which was in contrast to all other variables. 296 Salinity, temperature and $\mathrm{pH}$ characterized the second constrained axes, with $\mathrm{pH}$ being in contrast 297 to temperature and salinity (Fig. 3a). The species pattern clumped near the centroid of the 298 ordination diagram (Fig 3b) indicating that many species are found in intermediate environmental 299 conditions. Fewer species have a clear centroid in deeper waters, instead many species favour 300 higher temperatures and an above average salinity. Large variation appears in the direction of $\mathrm{pH}$ 301 and dissolved iron, as indicated by the strong scatter of species centroids (Fig. 3b).

302

303 Indicator species analysis

304 To characterize the different clusters with regard to faithful species, i.e. so-called indicator species 305 we conducted a multipattern indicator species analysis. We compared 15 different combinations 306 with an increasing number of clusters. From 355 species, we identified 56 to have a strong 307 association to one or more clusters. Fourtythree species were associated to one cluster only, while 308 twelve and one species were associated to two and three clusters, respectively (Table 3). Only two 309 species were found for the GIFR cluster, but more species from GIFR appear in combination with 310 other clusters.

311 Three of the clusters, the Deep North, the Deep South and the Coastal have indicator species 312 belonging to the genus Rhachotropis. While different species of a genus might be specialized on 
313 different diets, all Rhachotropis species are very good swimmers (Lörz, 2010). The Deep South 314 cluster has four Rhachotropis as indicator species. While the GIFR cluster only had two 315 endobenthic species, belonging to the family Ampeliscidae, which are not considered strong 316 swimmers (Peart, 2018). the combined GIFR and coastal cluster indicate Rhachotropis aculeata 317 (Lepechin, 1780) as an indicator - a species that is known to have a circum-Arctic distribution 318 (Lörz et al., 2018b). Caprella microtuberculata G. O. Sars, 1879 and Aeginella spinosa Boeck, 3191861 are indicator species of the combined coastal and GIFR cluster. These two species belong to 320 the amphipod group Caprellidae, skeleton or ghost shrimps, which are known for their clinging 321 lifestyle. The indicator species with the highest values, over 0.5 , are Cleippides quadricuspis 322 Heller, 1875 from the Deep North, Eusirus holmi Hansen, 1887 from the combined Coastal and 323 Deep North cluster and Rhachotropis thordisae Thurston, 1980 from the Deep South cluster 324 these three species are all large amphipods of several $\mathrm{cm}$ body length and known as predators. 325 (Lörz et al., 2018b)

326

327

328

329

330

331

332

333

334

335

336

337

338

339

340

341

342

\section{Diversity}

The number of aggregated hexagonal cells differed for each cluster, hence we had to apply a rarefaction and extrapolation analysis to make the three diversity measures comparable. The rarefaction of the summed abundances revealed that the two clusters "coastal" and "GIFR" have about twice the number of species than the deep-sea clusters (Fig 4a). This even holds when only the lowest comparable value of approximate 10,000 individuals are considered. Although there were so many individuals per cluster, the curves do not level off, indicating that still more sampling would be required to reach a plateau in species richness. The Shannon diversity (Fig $4 \mathrm{~b}$ ) considers the richness-abundance component of diversity. The "coastal" and "GIFR" clusters are at the same level of 60 effective species; the deep-sea clusters again have a much lower diversity, i.e. almost three times lower. All curves reach a plateau, indicating that there is little more diversity to expect when abundances are considered. Hence, only rare species might be added by future sampling. Considering the Simpson diversity (Fig. 4c), i.e. when no rare species but only dominant species have an influence on the diversity measure, then the "coastal" cluster becomes the most diverse cluster while the "GIFR" is only half as diverse as the coastal cluster. 
343 The richness pattern across the depth gradient showed high variation at depths above $1500 \mathrm{~m}$ with 344 richness values up to 79 species per station (Fig 5a). Most of the stations recorded rather few 345 species i.e. up to 10 species with an average of 20 species at the shallowest parts $(11 \mathrm{~m})$ and an 346 estimated richess of eight species at the lowest depths. The trend for the maximum number of 347 species aggregated per 100-m interval showed an unimodal pattern with a peak at depths around $348500 \mathrm{~m}$ and a much lower richness at depths lower than $1000 \mathrm{~m}$ (Fig 5b). These figures support the 349 finding that the Coastal and GIFR clusters are much more diverse than the deep-sea clusters (Fig $3505 \mathrm{c})$.

351

352 Discussion

353

354

355

356

\section{Environmental and historical imprints on amphipod distributions}

Distributional groupings given in the present study corresponded to earlier findings, in which 357 distinctive boundaries between a northern and a southern deep-sea fauna were inferred, while the 358 composition of the shallow-water fauna $(>500 \mathrm{~m})$ around Iceland was very similar (Weisshappel \& Svavarsson, 1998; Weisshappel, 2000; Bett, 2001; Weisshappel, 2001). Unsurprisingly, the spatial distribution of amphipods appeared to be most strongly influenced by bathymetry, salinity 361 and seafloor temperature. The latter two were interconnected and indicative of particular water masses (Puerta et al., 2020).

363 The presence of the GIFR is known as an effective barrier to disrupt the dispersal of benthic 364 organisms between the North Atlantic and the Nordic seas (Weisshappel \& Svavarsson, 1998; Brix \& Svavarsson, 2010; Schnurr et al., 2018). With a saddle depth averaging $600 \mathrm{~m}$ in the Strait of Denmark and $480 \mathrm{~m}$ between Iceland and the Faroe Islands and a maximum depth of $\mathrm{c}$. $840 \mathrm{~m}$, the depth increases towards the abyssal basins on each side of the ridge exceeding 3,000 m. Depth, or rather ecological and environmental variables that change with depth, such as hydrostatic pressure, temperature, food availability, or competition, have been demonstrated to have a large impact on species distributions (Rex \& Etter, 2010; Brown \& Thatje, 2011;

371 Tittensor et al., 2011). In contrast, there are several examples of amphipod species, mostly within 372 the more motile scavenger and predator guilds, with large depth distributions and thus at least the 
373 intrinsic capability to overcome topographical barriers (Lacey et al., 2018; Lörz et al., 2018a;

374 Weston et al., 2021).

375 The GIFR also marks the transition between different bodies of water, and hence the effects of

376 depth and water mass properties are intertwined. Generally, physical and chemical water mass

377 attributes such as temperature, salinity, $\mathrm{pH}$, organic matter, and dissolved oxygen play critical

378 roles in structuring benthic communities including microbes, fish, crustaceans, corals, and

379 sponges (Koslow, 1993; Weisshappel \& Svavarsson, 1998, Brix \& Svavarsson, 2010; Schnurr et

380 al., 2018; Puerta et al., 2020; Roberts et al., 2021). Reasons for this involve physiological

381 tolerances of larvae, juveniles and adults towards certain environmental conditions, dispersal

382 constraints invoked by density differences or current shear, as well as enhanced nutrient input

383 linked to hydrography (Puerta et al., 2020; Roberts et al., 2021).

384 Obviously, cold sub-zero temperatures in the Nordic sea basins restrict species distributions, as

385 only few species are pre-adapted to such low temperatures while withstanding high hydrostatic

386 pressures (Svavarsson et al., 1993; Brown \& Thatje, 2011). This is supported by the fact that

387 many amphipod species in our study prefer moderate conditions, at least in terms of temperature.

388 Initially, however, species originating from the North Atlantic had to overcome the GIFR and

389 enter the Nordic seas against the overflow water from the Denmark Strait and Faroe Bank

390 Channel (Yasuhara et al., 2008), the latter being limited to species with broad bathymetric

391 distributions or eurytherm "shallow"-water taxa. The presence of the GIFR is thereby inevitably

392 linked to the opening of the North-east Atlantic about 55 Mya, representing a barrier between the

393 Nordic seas and North Atlantic ever since (Hjartarson et al., 2017). Alternatively, species from

394 the North Pacific had to cross the Bering Strait sill, and experience subsequent trans-Arctic

395 migration (Hardy et al., 2011). While the shelf fauna represents a mixture of North Pacific, North

396 Atlantic and to a lesser extent endemic Arctic fauna (e.g., Svavarsson et al., 1993; Hardy et al.,

397 2011), large parts of the contemporary deep-sea fauna of the Arctic and Nordic seas likely

398 originate from the North Atlantic (e.g. Bluhm et al., 2011 and citations therein; Svavarsson et al., 399 1993).

400 In our indicator analysis, species were identified based on their predominant affiliation to certain 401 oceanographic conditions. Identifying areas of endemicity, Arfianti \& Costello (2020) defined 402 our study area as part of a larger region that comprised North American boreal, Arctic and North 403 Pacific areas. Our results, however, are consistent with the view that the deep-sea fauna of the 
404 Nordic seas appears to originate from shelf genera or less pronounced deep-sea taxa that were 405 able to cross the GIFR (Dahl, 1979; Just, 1980; Svavarsson et al., 1993). The study by Arfianti \& 406 Costello (2020) contained data for the entire Arctic and sub-Arctic regions, encompassing both 407 shelf and deep-sea areas, with the first reportedly representing a mixture of Atlantic, Arctic and 408 Pacific elements (see above). Contrasting distribution patterns in hyperbenthic Eusiridae and 409 Calliopiidae represent good examples to illustrate the barrier effect of the ridge; the family 410 Eusiridae, which is more prevalent in deep water, has only a few species north of the GIFR, 411 which is in contrast to the shallow water family Calliopiidae, whose species diversity is higher in 412 the north (Weisshappel, 2000; Weisshappel, 2001). Overall, Svavarsson et al. (1993) describes 413 the deep-sea fauna of the Arctic and Nordic seas as very young, probably less than 100,000 yrs. 414 old, due to the presence of the ridge and the adverse conditions prevailing in the northern regions 415 ("topographic and environmental filtering"). Accordingly, little time remained for speciation and 416 formation of endemic species (Svavarsson et al., 1993).

417 Our coastal amphipod assemblage, as well as the one associated with the GIFR, consisted of 418 indicator species with broad North Atlantic distributions. Over the past millennia the 419 biogeography of northern latitudes had been shaped by recurring glacial cycles (Darby et al., 420 2006). During the last glacial maximum (ending about 6,000 yrs ago; Darby et al., 2006). Arctic 421 shelves were largely covered by grounded ice sheets forcing the fauna towards more southerly 422 (North Atlantic) ice-free areas or deeper waters (Dunton, 1992; Darby et al., 2006). The latter 423 may have become the ancestors of today's Nordic deep-sea fauna (Nesis, 1984). While evidence 424 exists that at least parts of the shelf had remained ice-free and thus served as glacial refugia, 425 notably here Iceland and the Faroe Islands (Maggs et al., 2008; Hardy et al., 2011), most species 426 must have recolonized the previously ice-covered areas rather swiftly. Given the close overlap of 427 coastal and GIFR fauna in our study, the ridge could have provided a potential shallow-water 428 link for brooding taxa that has promoted the recolonization from suitable ice-free habitats.

429

\section{Diversity trends}

431 The comparison of the diversity between the environmental clusters showed that the diversity of 432 the shallow clusters (coastal and GIFR) was higher than that of the deep clusters north and south 433 of the ridge. While species richness had the highest number of effective species (Fig. 4a), its sole 434 use is usually not encouraged as it is heavily affected by sample size and shows high sensitivity 
435 in recording rare species (Jost, 2006). There were some profound differences between Hill 436 numbers - species richness, Shannon, and Simpson diversity - likely because each of these 437 indices scales rarity differently (Chao et al., 2014; Roswell et al., 2021; Fig. 4 b, c). The fact that 438 none of the richness-based rarefaction curves has stabilized yet, could therefore be an artifact; 439 many species have only been found once, either because they could not be identified to species 440 level or because only a small number of individuals were sampled during the historical missions. 441 The Simpson index, on the other hand, is considered as being most robust when sampling effort 442 differs strongly between samples, since it largely reflects patterns in the most common species 443 (Jost, 2006). Shannon diversity can be seen as a intermediate measure in terms of its responses to 444 sample size and rarity (Roswell et al., 2021). Overall, though, all estimates applied have their 445 merits and pitfalls, and typically using all three indices provides the best representation of the 446 diversity in a given area (Roswell et al., 2021). Nevertheless, a consistent pattern of a higher 447 diversity in the shallows - relative to the deep clusters - was evident in all three indices. In the 448 same way, analysis of the entire data set showed an unimodal pattern, with richness peaking at 449 around $500 \mathrm{~m}$, and then a sharp decline in richness with increasing depth (Fig. 5). Compared to 450 other studies that often show a peak between 2,000-3,000 m (cf. Rex \& Etter, 2010 and citations 451 therein), maximum richness in amphipods of the Nordic Seas seems to be much shallower and to 452 resemble patterns in isopods from the same area (Brix et al., 2018, but see Svavarsson, 1997). 453 However, it should be noted here that differences in sampling intensity between grid cells and 454 depth were a confounding factor in our study and the results therefore will have to be reassessed 455 with additional future sampling.

456 Combined historical and ecological explanations have been utilized to interpret the overall low 457 diversity of the Nordic basins compared to the other deep-sea regions (Svavarsson et al., 1993; 458 Bluhm et al., 2011). In general, it is believed that variation in energy supply (temperature and 459 productivity) affect deep-sea diversity (e.g. Woolley et al., 2016; Yasuhara \& Danovaro, 2016; 460 Jöst et al., 2019). However, cold temperatures per se do not seem to have a negative impact on 461 diversity, since benthic communities at sub-zero temperatures in the Southern Ocean abyss 462 appear to be extraordinarily rich (Brandt et al., 2007), but when coupled with the very low 463 productivity and geographical isolation of the Nordic basins, the diversity of invertebrates is 464 relatively low (Svavarsson et al., 1993; Egilsdottir et al., 2019; Jöst et al., 2019). In addition, 
465 antagonistic effects of high hydrostatic pressure and low temperatures that prevail in the deep 466 Nordic Sea basins could explain the low diversity there (Brown \& Thatje, 2011, 2014).

467 Notably, the diversity of the "Deep South" cluster in our study was as low as that of the Deep

468 North, which contrasts with the perception of an impoverished Nordic deep-sea fauna (Bouchet

469 \& Waren, 1979; Dahl, 1979; Rex et al., 1993; Svavarsson, 1997; Weisshappel \& Svavarsson,

470 1998; Jöst et al., 2019;). Although amphipods are typically less well presented in the deep sea

471 (e.g. when compared to isopods; Lörz et al., 2013), their 'deficiency' in Nordic waters was

472 established earlier. For example, Dahl (1979) found that gammaridean species in the Norwegian

473 Sea is a mere $20 \%$ of that in the North Atlantic. Yet, it is not clear whether this is a valid

474 conclusion, since pure richness comparisons are very susceptible to differences in sample sizes

475 and sample effort (see discussion above). In addition, different taxa north and south of the ridge

476 can have different diversity patterns resulting e.g. from their different evolutionary histories,

477 lifestyles (brooding vs. broadcaster) or physiological scope. This becomes very evident in

478 isopods, a sister group of the amphipods, where the diversity of the deep North Atlantic exceeds

479 that of the Nordic seas (Svavarsson, 1997).

480 Although not strictly comparable, but in line with our results, Egilsdottir et al. (2019), found

481 local deep-sea diversity of bivalve and gastropod molluscs north and south of the GIFR to be

482 equally low. They attributed this to specific oceanographic conditions prevailing at the deep

483 southern stations. In addition, changes in environmental conditions in the course of past glacial

484 maxima in the northern North Atlantic and in the North Sea were associated with cyclical

485 changes of low (glacial) and relatively increased (interglacial) diversity (Cronin \& Raymo, 1997;

486 Yasuhara et al., 2014). The related environmental consequences of these climatic changes, in

487 particular variation in bottom-water temperature, seasonality and meltwater runoff, evidently had

488 a strong impact on deep-sea diversity, with recent deep-sea fauna still in the process of

489 recovering from these events (Rex et al., 1993; Cronin \& Raymo, 1997; Wilson, 1998; Yasuhara

490 et al., 2008; Yasuhara et al., 2014; but see Jöst et al., 2019 and citations therein).

491 Compared to the deep-sea cluster, the diversity of the shallower coastal and GIFR clusters was

492 considerably higher (Fig 4a). This is in stark contrast to an allegedly poor amphipod fauna, for

493 example when compared to the South polar region (Arfianti \& Costello, 2020). Although a direct

494 comparison with other regions at complementary depth is still pending, it is already clear that the

495 shelf and upper slope amphipod fauna on the border between the North Atlantic and North Sea, 
496 consisting of more than 300 effective species, is not depleted (Fig. 4a). In comparison, De 497 Broyer \& Jazdzewska, (2014) counted 560 amphipod species for the entire Antarctic region 498 (south of the Polar front), which is considered to have a significantly higher amphipod diversity 499 relative to high northern latitudes (Arfianti \& Costello, 2020). In addition, through the 500 application of molecular techniques, but also additional sampling, especially of the deeper and 501 less frequently explored areas, more species are likely to be discovered for the northern region 502 (Bluhm et al., 2011; Jażdżewska et al., 2018; Lörz et al., 2018a; Schwentner \& Lörz, 2020). We 503 admit the comparison is slightly misleading, as cryptic species are discovered across all 504 environments at similar rates (Pfenninger \& Schwenk, 2007), plus different geological histories, 505 oceanographic settings, and the size of the Arctic vs. Antarctica, among other things represent 506 additional confounders regions should not be underestimated and presumably occupies globally 507 at least a middle ranking.

508

\section{Conclusions}

510 In amphipods, water mass properties appear to be the main force in delineating species 511 distributions at the boundary between the North Atlantic and the Nordic seas, with the GIFR 512 additionally hindering the exchange of deep-sea species between northern and southern deep-sea 513 basins. This pattern is largely congruent for all benthic but also hyperbenthic amphipod families. 514 Different factors are likely responsible for driving deep-sea diversity on each side of the ridge.

515 While impoverished amphipod communities in the Nordic basins are likely to be due to 516 topographical and environmental barrier effects, the southern deep-sea assemblage shows 517 similarly low diversity, presumably a response to variation in the oceanographic environment 518 over a range of temporal and spatial scales. In addition, bathymetric sampling constraints need to 519 be considered.

520 Since the Cenozoic Era (c. 65 mya) and more recently, the areas of the northern North Atlantic 521 and the Nordic seas have undergone profound climatic changes, from greenhouse to icehouse 522 conditions and vice versa, shaping the composition and distribution of the marine biota 523 (Piepenburg, 2005; Horton et al., 2020). Distinct temperature thresholds for the Arctic and 524 boreal benthic species point towards future range shifts (restrictions vs. extensions), which will 525 have a strong impact on the diversity in the region (Renaud et al., 2015). Our data showed a high 526 salinity and temperature-driven distribution of the amphipod assemblages, which also applies to 
527 a number of other taxa (Brix \& Svavarsson, 2010; Schnurr et al., 2018; Egilsdottir et al., 2019;

528 Jöst et al., 2019). Additional environmental variables may prove important in explaining 529 diversity and distribution, including seasonality in productivity, $\mathrm{pH}$ and ice cover (Yasuhara et 530 al., 2012). These are especially the ones that are predicted to change first due to recent climate 531 changes (e.g., Hoegh-Guldberg \& Bruno, 2010).

532 In our study, amphipods were highlighted as an important benthic component in Icelandic 533 waters. Since climate change is supposed to have an impact on several organizational levels 534 (populations, species, communities), in future studies, we aim to investigate the interaction of 535 local and regional processes on amphipod diversity as well as species-specific responses to better 536 understand potential effects of climate change in the Nordic seas.

537

538

539

\section{Acknowledgements}

We submitted the data to GFBIO and OBIS (Oceanographic Biodiversity Information System)

540 and are grateful for their processing. We thank all crew and scientific teams for all efforts taking,

541 sorting and identifying the samples. Furthermore, we acknowledge the datamanagement of the

542 IceAGE Amphipoda in the local DZMB database by Antje Fischer and Karen Jeskulke during

543 two amphipod determination workshops in 2016 and 2017.

544

545

546

547

548

\section{References}

549 Anderson MJ, and Willis TJ. 2003. Canonical analysis of principal coordinates: a useful method

550

551

552

553

554

555

556

557 of constrained ordination for ecology. Ecology 84:511-525 DOI: 10.1890/00129658(2003)084[0511:CAOPCA]2.0.CO;2.

Arfianti T, and Costello MJ. 2020. Global biogeography of marine amphipod crustaceans: latitude, regionalization, and beta diversity. Marine Ecology Progress Series 638:83-94 DOI: 10.3354/meps13272.

Assis J, Tyberghein L, Bosch S, Verbruggen H, Serrão EA, and De Clerck O. 2018. Bio-ORACLE v2. 0: Extending marine data layers for bioclimatic modelling. Global Ecology and Biogeography 27:277-284 DOI: 10.1111/geb.61293. 
558 Astthorsson OS, Gislason A, and Jonsson S. 2007. Climate variability and the Icelandic marine

559

560

561

562

563

564

565

566

567

568

569

570

571

572

573

574

575

576

577

578

579

580

581

582

583

584

585

586 ecosystem. Deep Sea Research Part II: Topical Studies in Oceanography 54:2456-2477 DOI: 10.1016/j.dsr2.2007.07.030.

Baco AR, Etter RJ, Ribeiro PA, Von der Heyden S, Beerli P, and Kinlan BP. 2016. A synthesis of genetic connectivity in deep-sea fauna and implications for marine reserve design. Molecular Ecology 25:3276-3298 DOI: 10.1111/mec.13689.

Bascompte J. 2009. Mutualistic networks. Frontiers in Ecology and the Environment 7:429-436

Bett BJ. 2001. UK Atlantic Margin Environmental Survey: introduction and overview of bathyal benthic ecology. Continental Shelf Research 21:917-956 DOI: 10.1016/S02784343(00)00119-9.

Birch CP, Oom SP, and Beecham JA. 2007. Rectangular and hexagonal grids used for observation, experiment and simulation in ecology. Ecological Modelling 206:347-359 DOI: 10.1016/j.ecolmodel.2007.03.041.

Birchenough SN, Reiss H, Degraer S, Mieszkowska N, Borja Á, Buhl-Mortensen L, Braeckman U, Craeymeersch J, De Mesel I, and Kerckhof F. 2015. Climate change and marine benthos: a review of existing research and future directions in the North Atlantic. Wiley Interdisciplinary Reviews: Climate Change 6:203-223 DOI: 10.1002/wcc.330.

Bluhm BA, Gebruk AV, Gradinger R, Hopcroft RR, Huettmann F, Kosobokova KN, Sirenko BI, and Weslawski JM. 2011. Arctic marine biodiversity: an update of species richness and examples of biodiversity change. Oceanography 24:232-248.

Boeck A. 1861. Bemaerkninger angaaende de ved de norske kyster forekommende Amphipoder. Forhandlinger ved de Skandinaviske Naturforskeres Mfte 8:631-677.

Bosch S, Tyberghein L, and De Clerck O. 2018. sdmpredictors: Species distribution modelling predictor datasets. $R$ package version 0.2 . 8 .

Bouchet P, and Warén A. 1979. Planktotrophig larval development in deep-water gastropods. Sarsia 64:37-40 DOI: 10.1080/00364827.1979.10411360.

Brandt A, Gooday AJ, Brandao SN, Brix S, Brökeland W, Cedhagen T, Choudhury M, Cornelius N, Danis B, and De Mesel I. 2007. First insights into the biodiversity and biogeography of the Southern Ocean deep sea. Nature 447:307-311 DOI: 10.1038/nature05827. 
587 Brix S, Lörz A-N, Jazdzewska AM, Hughes L, Tandberg AHS, Pabis K, Stransky B, Krapp-

588

589

590

591

592

593

594

595

596

597

598

599

600

601

602

603

604

605

606

607

608

609

610

611

612

613

614

615

616

Schickel T, and Sorbe JC. 2018. Amphipod family distributions around Iceland. ZooKeys:1 DOI: 10.3897/zookeys.731.19854.

Brix S, Meissner K, Stransky B, Halanych KM, Jennings RM, Kocot KM, and Svavarsson J. 2014. The IceAGE project-a follow up of BIOICE. Polish Polar Research 35: 141-150.

Brix S, and Svavarsson J. 2010. Distribution and diversity of desmosomatid and nannoniscid isopods (Crustacea) on the Greenland-Iceland-Faeroe Ridge. Polar Biology 33:515-530 DOI: $10.1007 / \mathrm{s} 00300-009-0729-8$.

Brown A, and Thatje S. 2011. Respiratory response of the deep-sea amphipod Stephonyx biscayensis indicates bathymetric range limitation by temperature and hydrostatic pressure. PLoS One 6:e28562 DOI: 10.1371/journal.pone.0028562.

Brown A, and Thatje S. 2014. Explaining bathymetric diversity patterns in marine benthic invertebrates and demersal fishes: physiological contributions to adaptation of life at depth. Biological Reviews 89:406-426.

Burnham KP, and Anderson DR. 2002. Model selection and multimodel inference: a practical information-theoretic approach. New York: Springer.

Burrows MT, Schoeman DS, Buckley LB, Moore P, Poloczanska ES, Brander KM, Brown C, Bruno JF, Duarte CM, and Halpern BS. 2011. The pace of shifting climate in marine and terrestrial ecosystems. Science 334:652-655 DOI: 10.1126/science.1210288.

Cáceres MD, Legendre P. 2009. Associations between species and groups of sites: indices and statistical inference. Ecology 90:3566-3574 DOI: 10.1890/08-1823.1.

Chao A, Chiu C-H, and Jost L. 2014. Unifying species diversity, phylogenetic diversity, functional diversity, and related similarity and differentiation measures through Hill numbers. Annual Review of Ecology, Evolution, and Systematics 45:297-324 DOI: 10.1146/annurev-ecolsys-120213-091540.

Chase JM, and Leibold MA 2003. Ecological Niches. Chicago: Chicago University Press. Clarke KR. 1993. Non-parametric multivariate analyses of changes in community structure. Austral Ecology 18:117-143 DOI: 10.1111/j.1442-9993.1993.tb00438.x.

Cronin TM, and Raymo ME. 1997. Orbital forcing of deep-sea benthic species diversity. Nature 385:624-627 DOI: 10.1038/385624a0.

PeerJ reviewing PDF | (2021:03:59448:2:0:NEW 7 Jul 2021) 
617 Dahl E. 1979. Deep-sea carrion feeding amphipods: evolutionary patterns in niche adaptation.

618

619

620

621

622

623

624

625

626

627

628

629

630

631

632

633

634

635

636

637

638

639

640

641

642

643

644

645

646 Oikos:167-175 DOI: 10.2307/3543994.

Darby DA, Polyak L, and Bauch HA. 2006. Past glacial and interglacial conditions in the Arctic Ocean and marginal seas-a review. Progress in Oceanography 71:129-144 DOI: 10.1016/j.pocean.2006.09.009.

Dauvin J-C, Alizier S, Weppe A, and Guðmundsson G. 2012. Diversity and zoogeography of Icelandic deep-sea Ampeliscidae (Crustacea: Amphipoda). Deep Sea Research Part I: Oceanographic Research Papers 68:12-23 DOI: 10.1016/j.dsr.2012.04.013.

De Broyer C, and Jazdzewski K. 1996. Biodiversity of the Southern Ocean: towards a new synthesis for the Amphipoda (Crustacea). Bollettino del Museo Civico di Storia Naturale di Verona.

De Cáceres M, Legendre P, and Moretti M. 2010. Improving indicator species analysis by combining groups of sites. Oikos 119:1674-1684 DOI: 10.1111/j.16000706.2010.18334.x.

Dunton K. 1992. Arctic biogeography: the paradox of the marine benthic fauna and flora. Trends in Ecology \& Evolution 7:183-189 DOI: 10.1016/0169-5347(92)90070-R.

Egilsdottir H, McGinty N, and Gudmundsson G. 2019. Relating depth and diversity of Bivalvia and Gastropoda in two contrasting sub-arctic marine regions. Frontiers in Marine Science 6:129 DOI: 10.3389/fmars.2019.00129.

Eiríksson J, Knudsen KL, Larsen G, Olsen J, Heinemeier J, Bartels-Jónsdóttir HB, Jiang H, Ran L, and Símonarson LA. 2011. Coupling of palaeoceanographic shifts and changes in marine reservoir ages off North Iceland through the last millennium. Palaeogeography, Palaeoclimatology, Palaeoecology 302:95-108 DOI: 10.1016/j.palaeo.2010.06.002.

Grantham BA, Eckert GL, and Shanks AL. 2003. Dispersal potential of marine invertebrates in diverse habitats: ecological archives A013-001-A1. Ecological Applications 13:108-116 DOI: 10.1890/1051-0761(2003)013[0108:DPOMII]2.0.CO;2.

Guerra-García J, De Figueroa JT, Navarro-Barranco C, Ros M, Sánchez-Moyano J, and Moreira J. 2014. Dietary analysis of the marine Amphipoda (Crustacea: Peracarida) from the Iberian Peninsula. Journal of Sea Research 85:508-517 DOI: 10.1016/j.seares.2013.08.006. 
647 Halpern BS, Walbridge S, Selkoe KA, Kappel CV, Micheli F, D'Agrosa C, Bruno JF, Casey KS,

648

649

650

651

652

653

654

655

656

657

658

659

660

661

662

663

664

665

666

667

668

669

670

671

672

673

674

675

676

Ebert C, and Fox HE. 2008. A global map of human impact on marine ecosystems. Science 319:948-952 DOI: 10.1126/science.1149345.

Hansen B, Østerhus S, Turrell WR, Jónsson S, Valdimarsson H, Hátún H, and Olsen SM. 2008. The inflow of Atlantic water, heat, and salt to the nordic seas across the GreenlandScotland ridge. In: Dickson RR, Meincke J, Rhines P, eds. Arctic-Subarctic Ocean Fluxes. Dordrecht: Springer, https://doi.org/10.1007/978-1-4020-6774-7_2.

Hansen HJ. 1887. Malacostraca marina Groenlandiae occidentalis: oversigt over det vestlige Grønlands fauna af malakostrake havkrebsdyr. Videnskabelige Meddelelser fra Dansk Naturhistorisk Forening 2-7:5-226.

Hardy SM, Carr CM, Hardman M, Steinke D, Corstorphine E, and Mah C. 2011. Biodiversity and phylogeography of Arctic marine fauna: insights from molecular tools. Marine Biodiversity 41:195-210 DOI: 10.1007/s12526-010-0056-X.

Harley CD, Randall Hughes A, Hultgren KM, Miner BG, Sorte CJ, Thornber CS, Rodriguez LF, Tomanek L, and Williams SL. 2006. The impacts of climate change in coastal marine systems. Ecology Letters 9:228-241 DOI: 10.1111/j.1461-0248.2005.00871.x.

Heller C. 1875. Neue Crustaceen und Pycnogoniden. Gesammelt während der k.k. österr.-ungar. Nordpol-Expedition. Vorläufige Mittheilung.- Sitzungsberichte der mathematischnaturwissenschaftlichen Classe der Kaiserlichen Akademie der Wissenschaften in Wien 71:609-612

Hiddink JG, Burrows MT, and García Molinos J. 2015. Temperature tracking by North Sea benthic invertebrates in response to climate change. Global Change Biology 21:117-129 DOI: $10.1111 / \mathrm{gcb} .12726$.

Hilário A, Metaxas A, Gaudron SM, Howell KL, Mercier A, Mestre NC, Ross RE, Thurnherr AM, and Young C. 2015. Estimating dispersal distance in the deep sea: challenges and applications to marine reserves. Frontiers in Marine Science 2:6 DOI: 10.3389/fmars.2015.00006.

Hjartarson Á, Erlendsson Ö, and Blischke A. 2017. The Greenland-Iceland-Faroe Ridge Complex. Geological Society, London, Special Publications 447:127-148 DOI: 10.1144/SP447.14.

PeerJ reviewing PDF | (2021:03:59448:2:0:NEW 7 Jul 2021) 
677 Hoegh-Guldberg O, and Bruno JF 2010. The impact of climate change on the world's marine

678

679

680

681

682

683

684

685

686

687

688

689

690

691

692

693

694

695

696

697

698

699

700

701

702

703

704

705

706

707 ecosystems. Science 328:1523-1528 DOI: 10.1126/science.1189930.

Horton T, Thurston MH, Vlierboom R, Gutteridge Z, Pebody CA, Gates AR, and Bett BJ. 2020. Are abyssal scavenging amphipod assemblages linked to climate cycles? Progress in Oceanography 184:102318 DOI: 10.1016/j.pocean.2020.102318.

Horton T, Lowry J, De Broyer C, Bellan-Santini D, Coleman CO, Corbari L, Costello MJ, Daneliya M, Dauvin JC, Fišer C, Gasca R, Grabowski M, Guerra-García JM, Hendrycks, E, Hughes L, Jaume D, Jazdzewski K, Kim YH, King R, Krapp-Schickel T, LeCroy S, Lörz ANA-N, Mamos T, Senna AR, Serejo C, Sket B, Souza-Filho JF, Tandberg AH, Thomas JD, Thurston M, Vader W, Väinölä R, Vonk R, White K, and Zeidler W. 2021. World Amphipoda Database. Amphipoda. Accessed through: World Register of Marine Species at: http://www.marinespecies.org/aphia.php?p=taxdetails\&id=1135 on 2021-0503

Hsieh T, Ma K, and Chao A. 2016. iNEXT: an R package for rarefaction and extrapolation of species diversity (Hill numbers). Methods in Ecology and Evolution 7:1451-1456 DOI: 10.1111/2041-210X.12613.

Jablonski D. 2008. Biotic interactions and macroevolution: extensions and mismatches across scales and levels. Evolution: International Journal of Organic Evolution 62:715-739 DOI: $10.1111 / j .1558-5646.2008 .00317 . x$.

Jablonski D and Roy K. 2003. Geographical range and speciation in fossil and living molluscs. Proceedings of the Royal Society of London. Series B: Biological Sciences 270:401-406.

Jażdżewska AM, Corbari L, Driskell A, Frutos I, and Havermans C. 2018. A genetic fingerprint of Amphipoda from Icelandic waters-the baseline for further biodiversity and biogeography studies. ZooKeys:55 DOI: 10.3897/zookeys.731.19931.

Jochumsen K, Schnurr SM, and Quadfasel D. 2016. Bottom temperature and salinity distribution and its variability around Iceland. Deep Sea Research Part I: Oceanographic Research Papers 111:79-90 DOI: 10.1016/j.dsr.2016.02.009.

Jones DO, Yool A, Wei CL, Henson SA, Ruhl HA, Watson RA, and Gehlen M. 2014. Global reductions in seafloor biomass in response to climate change. Global Change Biology 20:1861-1872 DOI: $10.1111 /$ gcb.12480. 
708 Jöst AB, Yasuhara M, Wei CL, Okahashi H, Ostmann A, Martínez Arbizu P, Mamo B, 709 Svavarsson J, and Brix S. 2019. North Atlantic Gateway: Test bed of deep-sea 710 macroecological patterns. Journal of Biogeography 46:2056-2066 DOI:

711 10.1111/jbi.13632.

712

713

714

715

716

717

718

719

720

721

722

723

724

725

726

727

728

729

730

731

732

733

734

735

736

737

738

Jost L. 2006. Entropy and diversity. Oikos 113:363-375 DOI: 10.1111/j.2006.00301299.14714.x.

Just J. 1980. Amphipoda (Crustacea) of the Thule area, northwest Greenland: faunistics and taxonomy. Copenhagen: Museum Tusculanum Press.

Kendall MA, and Aschan M. 1993. Latitudinal gradients in the structure of macrobenthic communities: a comparison of Arctic, temperate and tropical sites. Journal of Experimental Marine Biology and Ecology 172:157-169 DOI: 10.1016/00220981(93)90095-6.

Koslow JA. 1993. Community structure in North Atlantic deep-sea fishes. Progress in Oceanography 31:321-338 DOI: 10.1016/0079-6611(93)90005-X.

Lacey NC, Mayor DJ, Linley TD, and Jamieson AJ. 2018. Population structure of the hadal amphipod Bathycallisoma (Scopelocheirus) schellenbergi in the Kermadec Trench and New Hebrides Trench, SW Pacific. Deep Sea Research Part II: Topical Studies in Oceanography 155:50-60 DOI: 10.1016/j.dsr2.2017.05.001.

Leibold MA, Holyoak M, Mouquet N, Amarasekare P, Chase JM, Hoopes MF, Holt RD, Shurin JB, Law R, and Tilman D. 2004. The metacommunity concept: a framework for multi-scale community ecology. Ecology letters 7:601-613 DOI: 10.1111/j.14610248.2004.00608.x.

Lepechin I. 1780. Tres Oniscorum Species descriptae ab I Lepechin. Acta Academiae scientiarum imperialis petropolitanae. Petropoli,Typis Academiae scientiarum,17781786. Petropoli, Typis Academiae scientiarum,1778-1786.

Levin LA, Etter RJ, Rex MA, Gooday AJ, Smith CR, Pineda J, Stuart CT, Hessler RR, and Pawson D. 2001. Environmental influences on regional deep-sea species diversity. Annual review of ecology and systematics 32:51-93 DOI: 10.1146/annurev.ecolsys.32.081501.114002.

Lörz A-N, Brix S, Oldeland J, Coleman C, Peart R, Hughes L, Andres HG, Kaiser S, Kürzel K, Vader W, Tandberg AH, Stransky B, Svavarsson J, Guerra-García JM, Krapp-Schickel T. 
739

740

741

742

743

744

745

746

747

748

749

750

751

752

753

754

755

756

757

758

759

760

761

762

763

764

765

766

767

768

2021. Marine Amphipoda and environmental occurrence around Iceland. PANGAEA, https://doi.pangaea.de/10.1594/PANGAEA.931959

Lörz A-N. 2010. Deep-sea Rhachotropis (Crustacea: Amphipoda: Eusiridae) from New Zealand and the Ross Sea with key to the Pacific, Indian Ocean and Antarctic species. Zootaxa 2482:22-48.

Lörz A-N, Jażdżewska AM, and Brandt A. 2018a. A new predator connecting the abyssal with the hadal in the Kuril-Kamchatka Trench, NW Pacific. PeerJ 6:e4887 DOI: 10.7717/peerj.4887.

Lörz A-N, Tandberg AHS, Willassen E, and Driskell A. 2018b. Rhachotropis (Eusiroidea, Amphipoda) from the North East Atlantic. In: Brix S, Lörz A-N, Stransky B, Svavarsson J, eds. Amphipoda from the IceAGE-Project (Icelandic marine Animals: Genetics and Ecology). ZooKeys 731:75-101. https://doi.org/10.3897/zookeys.731.19814

Lörz A-N, Kaiser S, and Bowden D. 2013. Macrofaunal crustaceans in the benthic boundary layer from the shelf break to abyssal depths in the Ross Sea (Antarctica). Polar Biology 36:445-451 DOI: 10.1007/s00300-012-1269-1.

Lörz A-N, Tandberg AHS, Willassen E, and Driskell A. 2018b. Rhachotropis (Eusiroidea, Amphipoda) from the North East Atlantic. ZooKeys:75 DOI:

10.3897/zookeys.731.19814.

Lotze HK, Lenihan HS, Bourque BJ, Bradbury RH, Cooke RG, Kay MC, Kidwell SM, Kirby MX, Peterson CH, and Jackson JB. 2006. Depletion, degradation, and recovery potential of estuaries and coastal seas. Science 312:1806-1809 DOI: 10.1126/science.1128035.

Lourie SA, and Vincent AC. 2004. Using biogeography to help set priorities in marine conservation. Conservation Biology 18:1004-1020 DOI: 10.1111/j.15231739.2004.00137.x.

Lucey NM, Lombardi C, DeMarchi L, Schulze A, Gambi MC, and Calosi P 2015. To brood or not to brood: Are marine invertebrates that protect their offspring more resilient to ocean acidification? Scientific Reports 5:1-7 https://doi.org/10.1038/srep12009.

Maggs CA, Castilho R, Foltz D, Henzler C, Jolly MT, Kelly J, Olsen J, Perez KE, Stam W, and Väinölä R. 2008. Evaluating signatures of glacial refugia for North Atlantic benthic marine taxa. Ecology 89:108-122 DOI: 10.1890/08-0257.1. 
769 Nesis K. 1984. A hypothesis on the origin of western and eastern Arctic distribution areas of

770

771

772

773

774

775

776

777

778

779

780

781

782

783

784

785

786

787

788

789

790

791

792

793

794

795

796

797

798 marine bottom animals. Soviet Journal of Marine Biology 9:235-243.

Nyssen F, Brey T, Lepoint G, Bouquegneau J-M, De Broyer C, and Dauby P. 2002. A stable isotope approach to the eastern Weddell Sea trophic web: focus on benthic amphipods. Polar Biology 25:280-287 DOI: 10.1007/s00300-001-0340-0.

Oksanen J, Blanchet FG, Friendly M, Kindt R, Legendre P, McGlinn D, Minchin PR, O'Hara RB, Simpson GL, Solymos P, Stevens MHH, Szoecs E, Wagner H. 2019. vegan: Community Ecology Package. $R$ package version 2.5-6.

Olafsson J, Olafsdottir SR, Benoit-Cattin A, Danielsen M, Arnarson TS, and Takahashi T. 2009. Rate of Iceland Sea acidification from time series measurements. Biogeosciences 6: 261266. DOI: $10.5194 /$ bg-6-2661-2009.

Oug E, Bakken T, Kongsrud JA, and Alvestad T. 2017. Polychaetous annelids in the deep Nordic Seas: Strong bathymetric gradients, low diversity and underdeveloped taxonomy. Deep Sea Research Part II: Topical Studies in Oceanography 137:102-112 DOI: 10.1016/j.dsr2.2016.06.016.

Peart RA. 2018. Ampeliscidae (Crustacea, Amphipoda) from the IceAGE expeditions. In: Brix S, Lörz A-N, Stransky B, Svavarsson J (Eds),eds. Amphipoda from the IceAGE-Project (Icelandic marine Animals: Genetics and Ecology). ZooKeys 731:145-173. https://doi.org/10.3897/zookeys.731.19948

Pfenninger M, and Schwenk K. 2007. Cryptic animal species are homogeneously distributed among taxa and biogeographical regions. BMC evolutionary biology 7:1-6 DOI: 10.1186/1471-2148-7-121.

Piepenburg D. 2005. Recent research on Arctic benthos: common notions need to be revised. Polar Biology 28:733-755 DOI: 10.1007/s00300-005-0013-5.

Piepenburg D, Archambault P, Ambrose WG, Blanchard AL, Bluhm BA, Carroll ML, Conlan KE, Cusson M, Feder HM, and Grebmeier JM. 2011. Towards a pan-Arctic inventory of the species diversity of the macro-and megabenthic fauna of the Arctic shelf seas. Marine Biodiversity 41:51-70 DOI: 10.1007/s12526-010-0059-7.

Puerta P, Johnson C, Carreiro-Silva M, Henry L-A, Kenchington E, Morato T, Kazanidis G, Rueda JL, Urra J, and Ross S. 2020. Influence of water masses on the biodiversity and 
799

800

801

802

803

804

805

806

807

808

809

810

811

812

813

814

815

816

817

818

819

820

821

822

823

824

825

826

827

biogeography of deep-sea benthic ecosystems in the North Atlantic. Frontiers in Marine Science 7:239 DOI: 10.3389/fmars.2020.00239.

QGIS Development Team. 2019. QGIS Geographic Information System. Open Source Geospatial Foundation.

Renaud PE, Sejr MK, Bluhm BA, Sirenko B, and Ellingsen IH. 2015. The future of Arctic benthos: expansion, invasion, and biodiversity. Progress in Oceanography 139:244-257 DOI: 10.1016/j.pocean.2015.07.007.

Renaud PE, Webb T, Bjørgesæter A, Karakassis I, Kedra M, Kendall M, Labrune C, Lampadariou N, Somerfield P, and Wlodarska-Kowalczuk M. 2009. Continental-scale patterns in benthic invertebrate diversity: insights from the MacroBen database. Marine Ecology Progress Series 382:239-252 DOI: 10.3354/meps07963.

Rex MA, Crame JA, Stuart CT, and Clarke A. 2005. Large-scale biogeographic patterns in marine mollusks: a confluence of history and productivity? Ecology 86:2288-2297 DOI: 10.1890/04-1056.

Rex MA, and Etter RJ. 2010. Deep-sea biodiversity: pattern and scale. Cambridge: Harvard University Press.

Rex MA, Stuart CT, and Coyne G. 2000. Latitudinal gradients of species richness in the deep-sea benthos of the North Atlantic. Proceedings of the National Academy of Sciences 97:40824085 DOI: 10.1073/pnas.050589497.

Rex MA, Stuart CT, Hessler RR, Allen JA, Sanders HL, and Wilson GD. 1993. Global-scale latitudinal patterns of species diversity in the deep-sea benthos. Nature 365:636-639 DOI: 10.1038/365636a0.

Richardson AJ, and Poloczanska ES. 2008. Under-resourced, under threat. Science 320 (5881): 1294-1295. DOI: 10.1126/science.1156129.

Roberts E, Bowers D, Meyer H, Samuelsen A, Rapp H, and Cárdenas P. 2021. Water masses constrain the distribution of deep-sea sponges in the North Atlantic Ocean and Nordic Seas. Marine Ecology Progress Series 659:75-96 DOI: 10.3354/meps13570.

Roswell M, Dushoff J, and Winfree R. 2021. A conceptual guide to measuring species diversity. Oikos 130:321-338 DOI: 10.1111/oik.07202. 
828 Sars GO. 1879. Crustacea et Pycnogonida nova in itinere 2do et 3tio expeditionis Norvegicae

829

830

831

832

833

834

835

836

837

838

839

840

841

842

843

844

845

846

847

848

849

850

851

852

853

854

855

856

anno $1877 \& 78$ collecta (prodromus descriptionis). Archiv for Mathematik og Naturvidenskab 4:427-476.

Schnurr S, Osborn KJ, Malyutina M, Jennings R, Brix S, Driskell A, Svavarsson J, and Arbizu PM. 2018. Hidden diversity in two species complexes of munnopsid isopods (Crustacea) at the transition between the northernmost North Atlantic and the Nordic Seas. Marine Biodiversity 48:813-843 DOI: 10.1007/s12526-018-0877-6.

Schwentner M, and Lörz A-N. 2020. Population genetics of cold-water coral associated Pleustidae (Crustacea, Amphipoda) reveals cryptic diversity and recent expansion off Iceland. Marine Ecology:e12625 DOI: 10.1111/maec.12625.

Scrucca L, Fop M, Murphy TB, and Raftery AE. 2016. mclust 5: clustering, classification and density estimation using Gaussian finite mixture models. The R journal 8:289 DOI: 10.32614/RJ-2016-021.

Seidov D, Antonov J, Arzayus K, Baranova O, Biddle M, Boyer T, Johnson D, Mishonov A, Paver C, and Zweng M. 2015. Oceanography north of $60^{\circ} \mathrm{N}$ from World Ocean Database. Progress in Oceanography 132. http://dx.doi.org/10.1016/j. pocean.2014.02.003.

Shannon CE, and Weaver W. 1949. The Mathematical Theory of Communication. Urbana and Chicago: University of Illinois Press.

Simpson EH. 1949. Measurement of diversity. Nature 163:688-688 DOI: 10.1038/163688a0.

Stephensen K. 1933. The Godthaab expedition 1928. Amphipoda. Meddelelser om Grønland 79:1-88.

Stephensen K. 1938. The Amphipoda of N. Norway and Spitsbergen with adjacent waters. Fasc. 2. Tromsø Museums Skrifter 3:141-278.

Stephensen K. 1942. The Amphipoda of N. Norway and Spitsbergen with adjacent waters. Fasc. 3. Tromsø Museums Skrifter 3:363-526.

Stephensen K. 1944a. The Zoology of East Greenland. Amphipoda. Meddelelser om Grønland 121:1-165.

Stephensen K. 1944b. Crustacea Malacostraca VIII: Amphipoda IV. The Danish Ingolf Expedition 3:1-54.

Peer] reviewing PDF | (2021:03:59448:2:0:NEW 7 Jul 2021) 
857 Stransky B, and Brandt A. 2010. Occurrence, diversity and community structures of peracarid

858

859

860

861

862

863

864

865

866

867

868

869

870

871

872

873

874

875

876

877

878

879

880

881

882

883

884

885

886

887

crustaceans (Crustacea, Malacostraca) along the southern shelf of Greenland. Polar Biology 33:851-867 DOI: 10.1007/s00300-010-0785-0.

Stuart CT, and Rex MA. 2009. Bathymetric patterns of deep-sea gastropod species diversity in 10 basins of the Atlantic Ocean and Norwegian Sea. Marine Ecology 30:164-180 DOI: 10.1111/j.1439-0485.2008.00269.x.

Svavarsson J, Stromberg J-O, and Brattegard T. 1993. The deep-sea asellote (Isopoda, Crustacea) fauna of the Northern Seas: species composition, distributional patterns and origin. Journal of Biogeography:537-555. DOI: 10.2307/2845725.

Svavarsson JR. 1997. Diversity of isopods (Crustacea): new data from the Arctic and Atlantic Oceans. Biodiversity \& Conservation 6:1571-1579 DOI: 10.1023/A:1018322704940.

Thurston MH. 1980. Abyssal benthic Amphipoda (Crustacea) from the East Iceland Basin. 1. The genus Rhachotropis. Bulletin of the British Museum (Natural History), Zoology, 38, 1, 43-67.

Tittensor DP, Rex MA, Stuart CT, McClain CR, and Smith CR. 2011. Species-energy relationships in deep-sea molluscs. Biology Letters 7:718-722 DOI: 10.1098/rsbl.2010.1174.

Weisshappel J, and Svavarsson J. 1998. Benthic amphipods (Crustacea: Malacostraca) in Icelandic waters: diversity in relation to faunal patterns from shallow to intermediate deep Arctic and North Atlantic Oceans. Marine Biology 131:133-143 DOI: $10.1007 / \mathrm{s} 002270050304$.

Weisshappel JB. 2000. Distribution and diversity of the hyperbenthic amphipod family Eusiridae in the different seas around the Greenland-Iceland-Faeroe-Ridge. Sarsia 85:227-236 DOI: $10.1080 / 00364827.2000 .10414575$.

Weisshappel JB. 2001. Distribution and diversity of the hyperbenthic amphipod family Calliopiidae in the different seas around the Greenland-Iceland-Faeroe-Ridge. Sarsia 86:143-151 DOI: 10.1080/00364827.2001.10420469.

Weston JN, Peart RA, Stewart HA, Ritchie H, Piertney SB, Linley TD, and Jamieson AJ. 2021. Scavenging amphipods from the Wallaby-Zenith Fracture Zone: Extending the hadal paradigm beyond subduction trenches. Marine Biology 168:1-14 DOI: 10.1007/s00227020-03798-4.

PeerJ reviewing PDF | (2021:03:59448:2:0:NEW 7 Jul 2021) 
888 Wilson GD. 1998. Historical influences on deep-sea isopod diversity in the Atlantic Ocean. Deep 889 Sea Research Part II: Topical Studies in Oceanography 45:279-301 DOI:

$890 \quad 10.1016 / \mathrm{S} 0967-0645(97) 00046-5$.

891 Woolley SN, Tittensor DP, Dunstan PK, Guillera-Arroita G, Lahoz-Monfort JJ, Wintle BA, 892 Worm B, and O'Hara TD. 2016. Deep-sea diversity patterns are shaped by energy 893 availability. Nature 533:393-396 DOI: 10.1038/nature17937.

894 Yasuhara M, Cronin TM, Demenocal PB, Okahashi H, and Linsley BK. 2008. Abrupt climate 895 change and collapse of deep-sea ecosystems. Proceedings of the National Academy of 896 Sciences 105:1556-1560 DOI: 10.1073/pnas.0705486105.

897 Yasuhara M, and Danovaro R. 2016. Temperature impacts on deep-sea biodiversity. Biological 898 Reviews 91:275-287 DOI: 10.1111/brv.12169.

899 Yasuhara M, Hunt G, van Dijken G, Arrigo KR, Cronin TM, and Wollenburg JE. 2012. Patterns 900 and controlling factors of species diversity in the Arctic Ocean. Journal of Biogeography 901 39:2081-2088 DOI: 10.1111/j.1365-2699.2012.02758.x.

902 Yasuhara M, Okahashi H, Cronin T, Rasmussen T, and Hunt G. 2014. Deep-sea biodiversity 903 response to deglacial and Holocene abrupt climate changes in the North Atlantic Ocean. 904 Global Ecology and Biogeography 23:957-967 DOI: 10.1111/geb.12178. 
Figure 1

Four environmental clusters

Map of the outlines for four identified environmental clusters in the North Atlantic. The Greenland-Faroe-Iceland ridge (GIFR) extends from west to east and is, like the coastal cluster, partly interrupted due to the coarse resolution of the hexagonal cells of $1^{\circ}$ in eastwest direction, $(n=469)$.

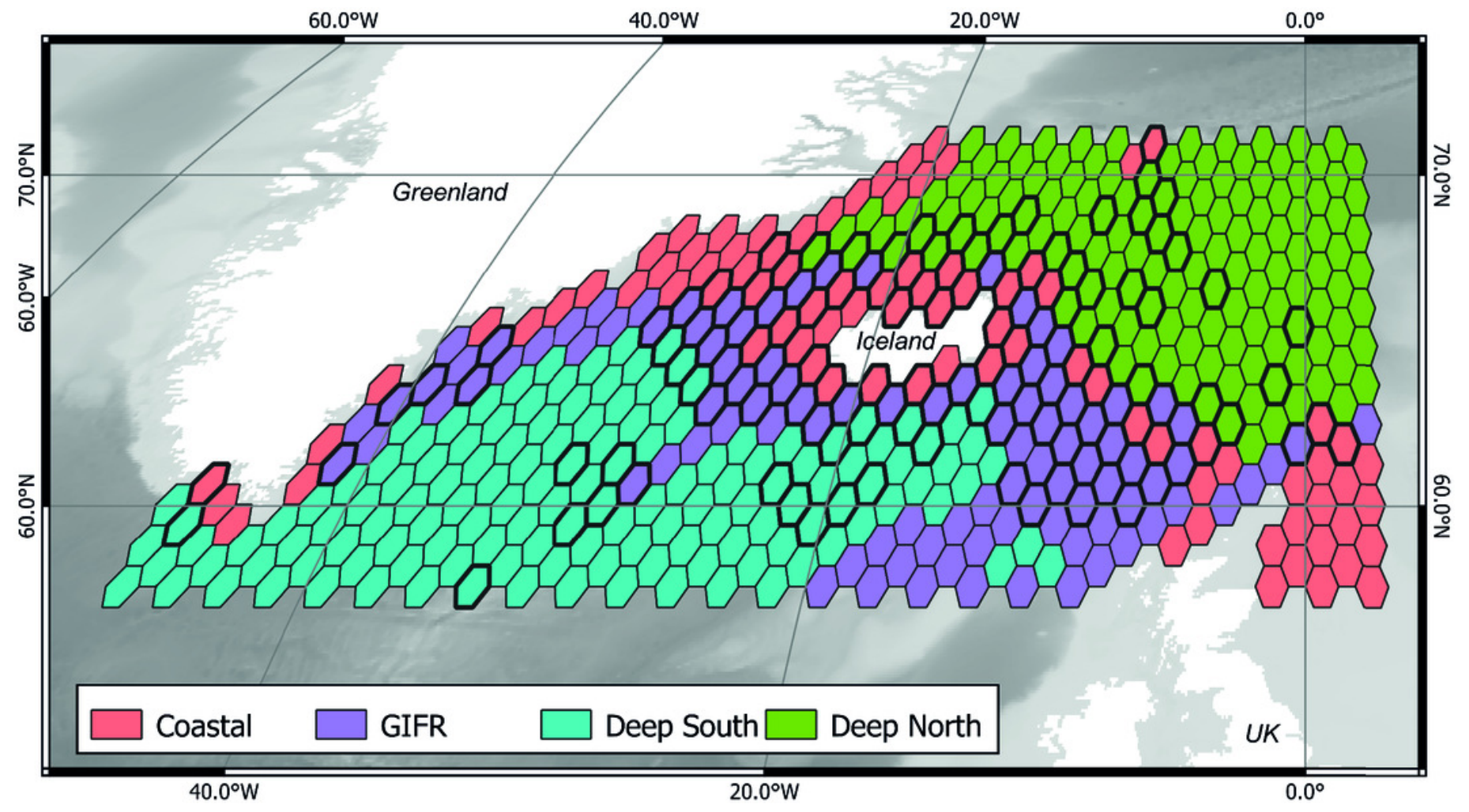


Figure 2

Environmental parameters

Characterization of the four environmental clusters by the environmental parameters with box-whisker plots. For abbreviations refer to table 1 . An extended table with numeric information can be found in the appendix.

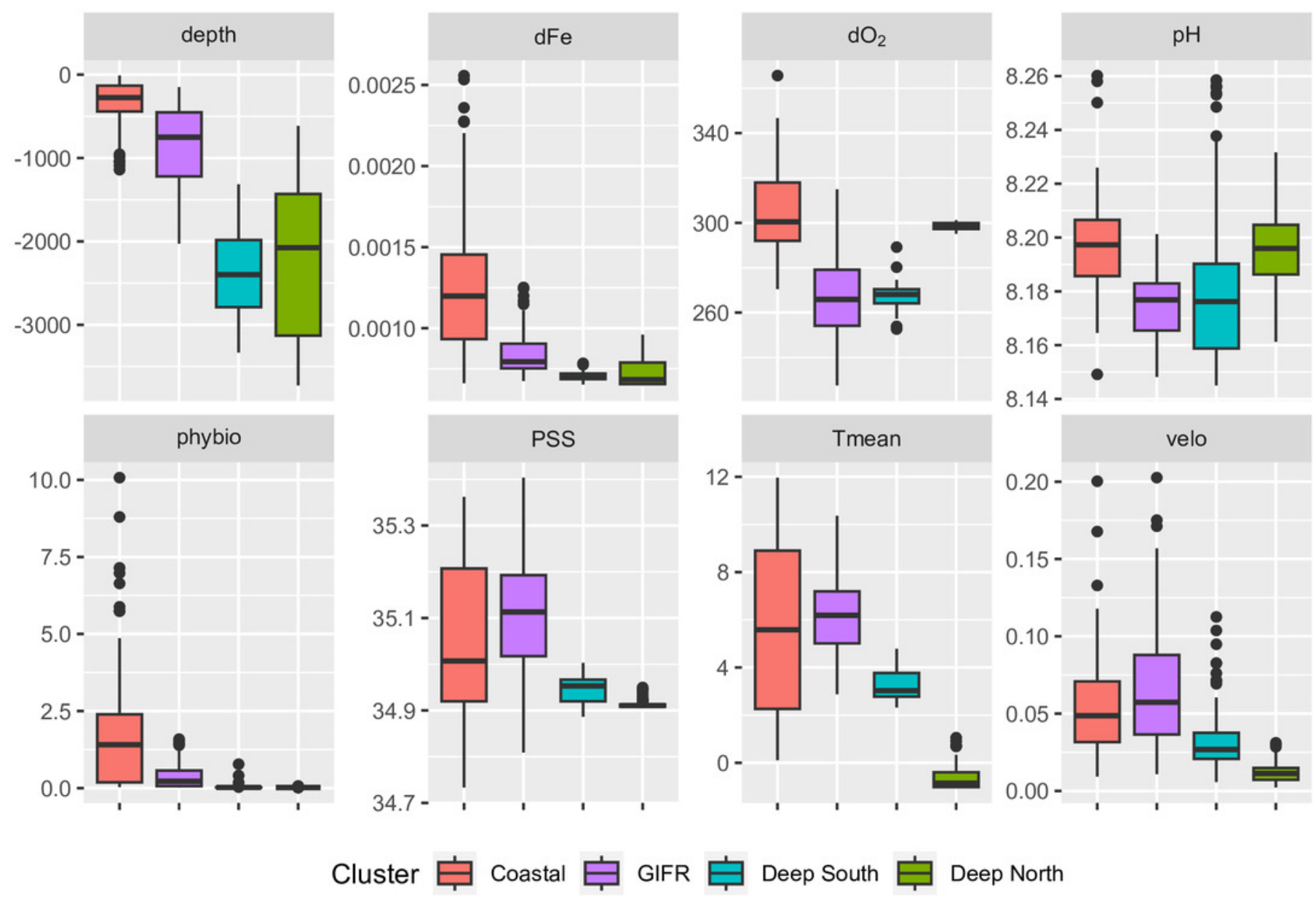


Figure 3

Constrained analysis of principal coordinates

Constrained analysis of principal coordinates (CAP) based on Jaccard distances. (A) Scaling is based on site scores, (B) scaling is based on species scores (red dots) - note the differences of the axes. Arrows point into the direction of largest correlation with species and site scores. The 0,0 coordinate reflects the centroid of each variable. The environmental clusters still overlap considerably in their species composition as reflected by the low ANOSIM-R statistic.
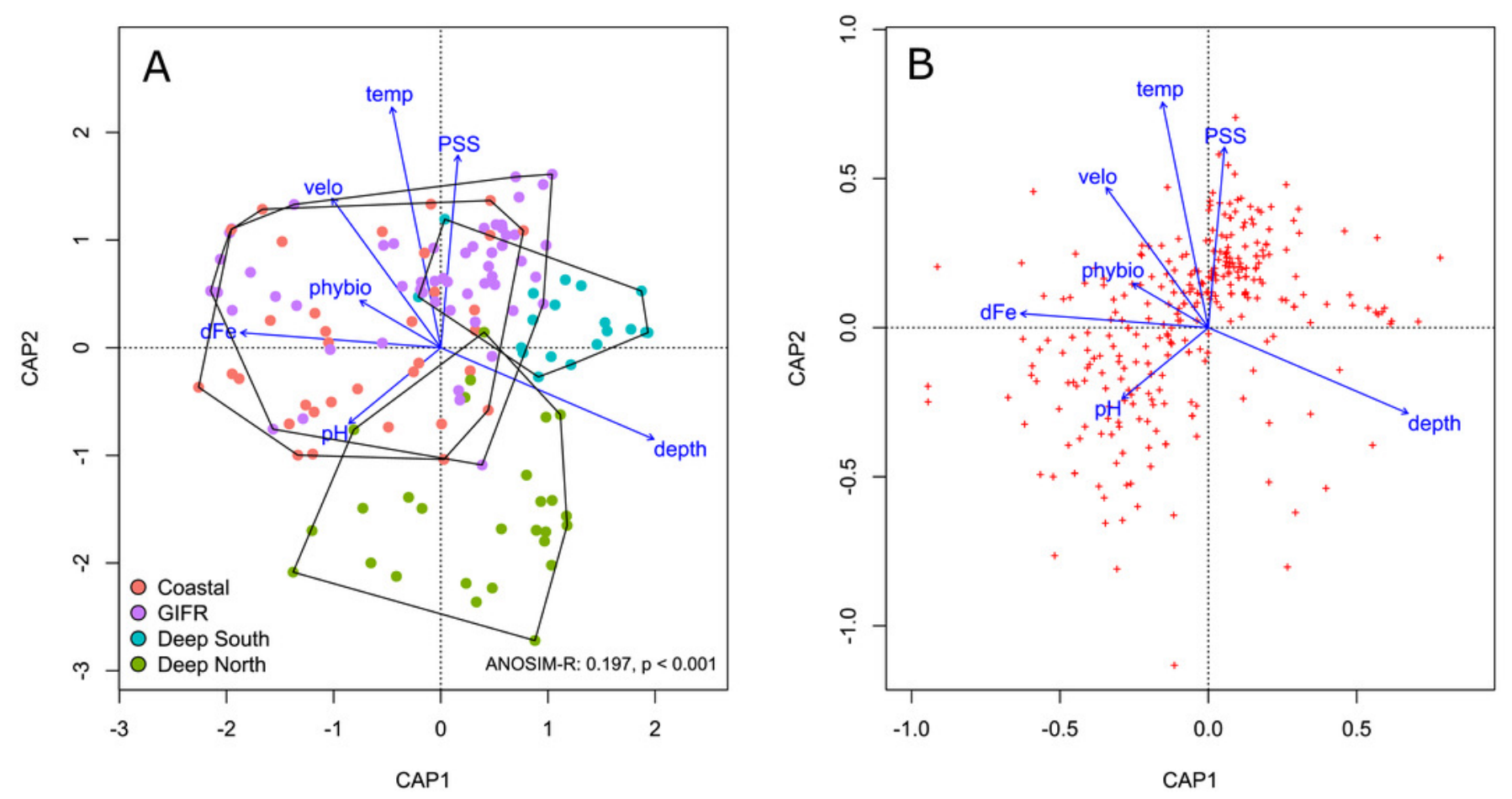
Figure 4

Rarefaction-extrapolation of diversity indices per cluster.

Figure 4. Rarefaction-extrapolation of diversity indices per cluster. The diversity indices (A) richness, (B) Shannon, and (C) Simpson, represent an increasing importance of abundant species. The unit of the $y$-axis is the effective number of species.
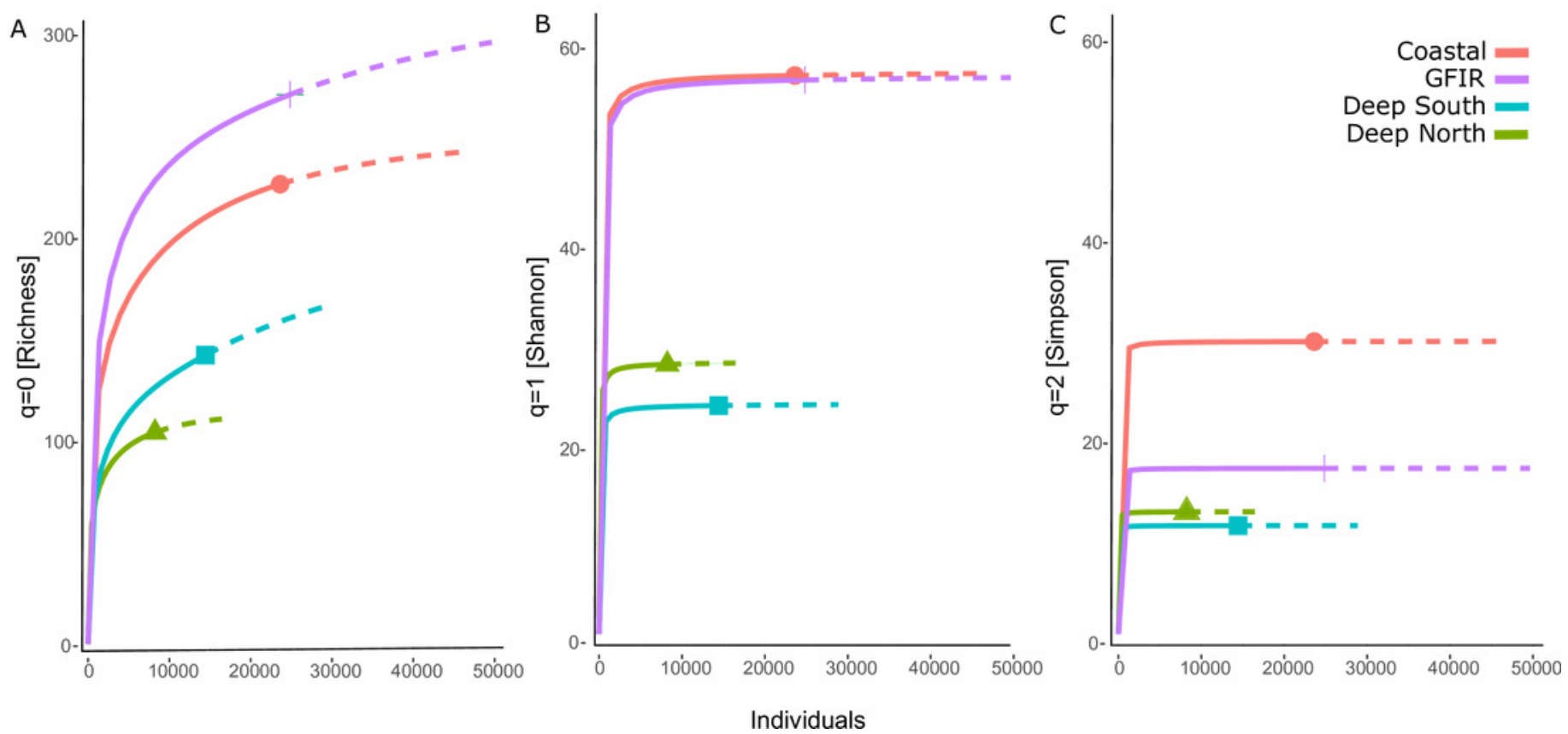


\section{Figure 5}

Amphipod species diversity pattern along a depth gradient

Amphipod species diversity pattern along a depth gradient. (A) Richness values per station and coloured according to the environmental clusters. The blue dashed line represents the Poisson GLM. (B) Maximum number of amphipod species per 100-m interval. A Loess smoother represented by the red dashed line is plotted to better visualize the pattern. (C) Bars show the depth ranges in meters for each of the four environmental clusters. Colours according to the legend in $A$.
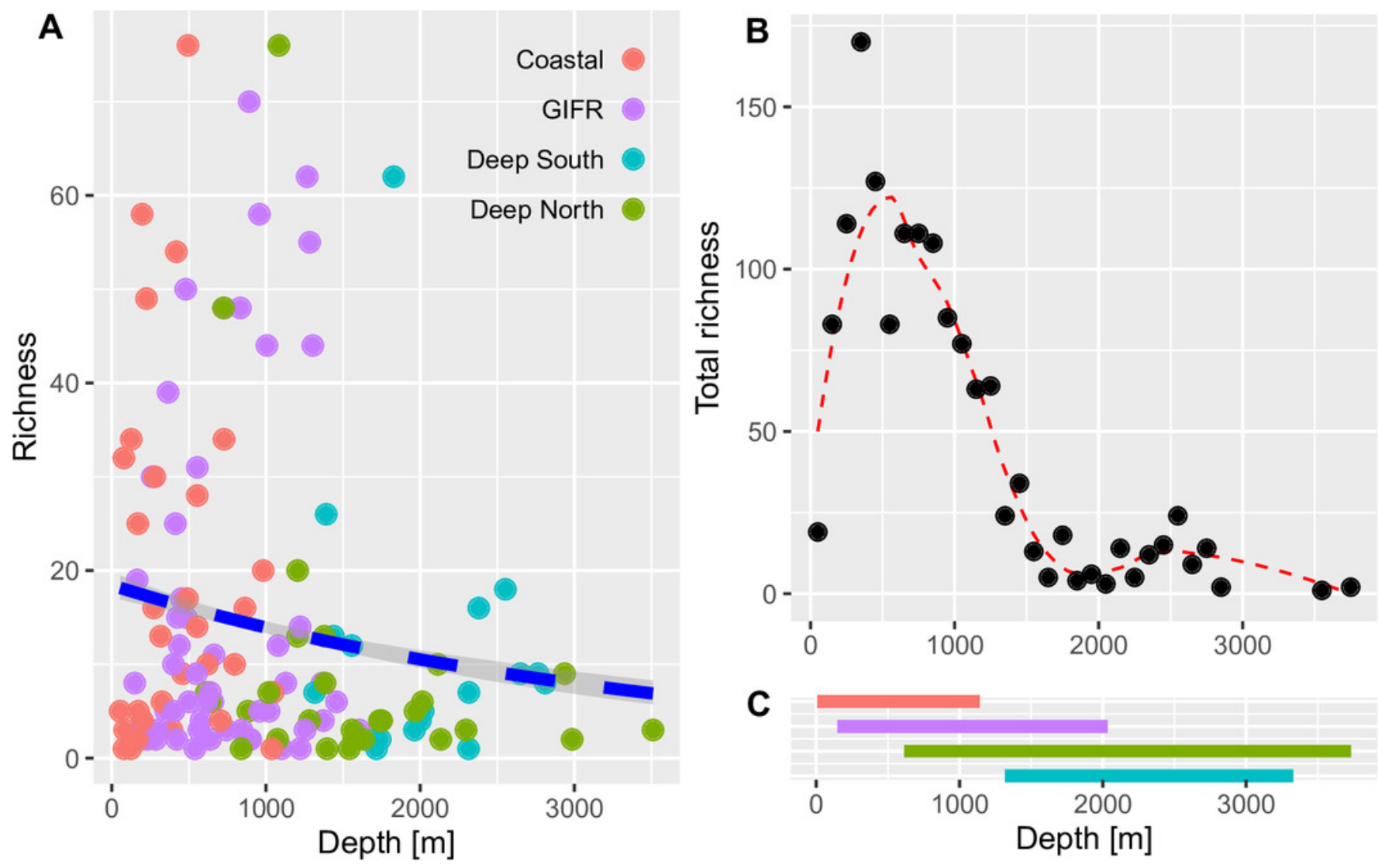


\section{Table 1 (on next page)}

\section{Environmental parameters}

Environmental parameters initially extracted from the BIO-ORACLE 2.0 database. All parameters are long-term maxima at minimum depth, except bathymetry, which represents the deepest (=minimum) depth measured. 
1 Table 1. Environmental parameters initially extracted from the BIO-ORACLE 2.0 database. All parameters are long-term maxima

2 at minimum depth, except bathymetry which represents the deepest (=minimum) depth measured.

\begin{tabular}{|c|c|c|c|}
\hline Acronym & Parameter & Units & Source \\
\hline depth & Bathymetry & meters & $\begin{array}{l}\text { GEBCO URL: http://gebco.net EMODnet } \\
\text { Bathymetry URL: http://www.emodnet- } \\
\text { bathymetry.eu/ }\end{array}$ \\
\hline chla & $\begin{array}{l}\text { Chlorophyll } \\
\text { concentration }\end{array}$ & $\mathrm{mg} / \mathrm{m}^{2}$ & $\begin{array}{l}\text { Global Ocean Biogeochemistry NON } \\
\text { ASSIMILATIVE Hindcast (PISCES) URL: } \\
\text { http://marine.copernicus.eu/ }\end{array}$ \\
\hline vel & Current velocity & $\mathrm{m} / \mathrm{s}$ & $\begin{array}{l}\text { Global Ocean Physics Reanalysis ECMWF } \\
\text { ORAP5.0 (1979-2013) URL: } \\
\text { http://marine.copernicus.eu/ }\end{array}$ \\
\hline $\mathrm{dO}_{2}$ & $\begin{array}{l}\text { Dissolved oxygen } \\
\text { concentration }\end{array}$ & $\mu \mathrm{mol} / \mathrm{m}^{2}$ & $\begin{array}{l}\text { Global Ocean Biogeochemistry NON } \\
\text { ASSIMILATIVE Hindcast (PISCES) URL: } \\
\text { http://marine.copernicus.eu/ }\end{array}$ \\
\hline $\mathrm{dFe}$ & $\begin{array}{l}\text { Dissolved iron } \\
\text { concentration }\end{array}$ & $\mu \mathrm{mol} / \mathrm{m}^{2}$ & $\begin{array}{l}\text { Global Ocean Biogeochemistry NON } \\
\text { ASSIMILATIVE Hindcast (PISCES) URL: } \\
\text { http://marine.copernicus.eu/ }\end{array}$ \\
\hline $\mathrm{dP}$ & $\begin{array}{l}\text { Phosphate } \\
\text { concentration }\end{array}$ & $\mu \mathrm{mol} / \mathrm{m}^{2}$ & $\begin{array}{l}\text { Global Ocean Biogeochemistry NON } \\
\text { ASSIMILATIVE Hindcast (PISCES) URL: } \\
\text { http://marine.copernicus.eu/ }\end{array}$ \\
\hline $\mathrm{dNO}_{3}$ & $\begin{array}{l}\text { Nitrate } \\
\text { concentration }\end{array}$ & $\mu \mathrm{mol} / \mathrm{m}^{2}$ & $\begin{array}{l}\text { Global Ocean Biogeochemistry NON } \\
\text { ASSIMILATIVE Hindcast (PISCES) URL: } \\
\text { http://marine.copernicus.eu/ }\end{array}$ \\
\hline temp & $\begin{array}{l}\text { Sea water } \\
\text { temperature }\end{array}$ & $\begin{array}{l}\text { degrees } \\
\text { Celcius }\end{array}$ & $\begin{array}{l}\text { Global Ocean Physics Reanalysis ECMWF } \\
\text { ORAP5.0 (1979-2013) URL: } \\
\text { http://marine.copernicus.eu/ }\end{array}$ \\
\hline phybio & $\begin{array}{l}\text { Carbon } \\
\text { phytoplankton } \\
\text { biomass }\end{array}$ & $\mu \mathrm{mol} / \mathrm{m}^{2}$ & $\begin{array}{l}\text { Global Ocean Biogeochemistry NON } \\
\text { ASSIMILATIVE Hindcast (PISCES) URL: } \\
\text { http://marine.copernicus.eu/ }\end{array}$ \\
\hline prod & Primary production & $\mathrm{g} / \mathrm{m}^{2} / \mathrm{day}$ & $\begin{array}{l}\text { Global Ocean Biogeochemistry NON } \\
\text { ASSIMILATIVE Hindcast (PISCES) URL: } \\
\text { http://marine.copernicus.eu/ }\end{array}$ \\
\hline Salinity & Sea water salinity & PSS & $\begin{array}{l}\text { Global Ocean Physics Reanalysis ECMWF } \\
\text { ORAP5.0 (1979-2013) URL: } \\
\text { http://marine.copernicus.eu/ }\end{array}$ \\
\hline
\end{tabular}




\begin{tabular}{llll}
\hline Acronym & Parameter & Units & Source \\
\hline \multirow{2}{*}{$\mathrm{SiO}_{4}$} & $\begin{array}{l}\text { Silicate } \\
\text { concentration }\end{array}$ & $\mu \mathrm{mol} / \mathrm{m}^{2}$ & $\begin{array}{l}\text { Global Ocean Biogeochemistry NON } \\
\text { ASSIMILATIVE Hindcast (PISCES) URL: } \\
\end{array}$ \\
& & http://marine.copernicus.eu/ \\
\hline
\end{tabular}

3 
Table 2 (on next page)

Amphipoda Species

Amphipoda species, authorities and family 


\begin{tabular}{|c|c|c|c|}
\hline Nr & Species & Authority & Family \\
\hline 1 & Abludomelita gladiosa & (Spence Bate, 1862) & Melitidae \\
\hline 2 & Abludomelita obtusata & (Montagu, 1813) & Melitidae \\
\hline 3 & Acanthonotozoma cristatum & (Ross, 1835) & Acanthonotozomatidae \\
\hline 4 & Acanthonotozoma serratum & (O. Fabricius, 1780) & Acanthonotozomatidae \\
\hline 5 & Acanthostepheia malmgreni & (Goës, 1866) & Oedicerotidae \\
\hline 6 & Aceroides latipes & (G.O. Sars, 1883) & Oedicerotidae \\
\hline 7 & Aeginella spinosa & Boeck, 1861 & Caprellidae \\
\hline 8 & Aeginina longicornis & (Krøyer, 1843) & Caprellidae \\
\hline 9 & Ambasia atlantica & (H. Milne Edwards, 1830) & Ambasiidae \\
\hline 10 & Ampelisca aequicornis & Bruzelius, 1859 & Ampeliscidae \\
\hline 11 & Ampelisca amblyops & G.O. Sars, 1891 & Ampeliscidae \\
\hline 12 & Ampelisca compacta & Norman, 1882 & Ampeliscidae \\
\hline 13 & Ampelisca eschrichtii & Krøyer, 1842 & Ampeliscidae \\
\hline 14 & Ampelisca gibba & G.O. Sars, 1883 & Ampeliscidae \\
\hline 15 & Ampelisca islandica & Bellan-Santini \& Dauvin, 1996 & Ampeliscidae \\
\hline 16 & Ampelisca macrocephala & Liljeborg, 1852 & Ampeliscidae \\
\hline 17 & Ampelisca odontoplax & G. O. Sars, 1879 & Ampeliscidae \\
\hline 18 & Ampelisca sp. A & Krøyer, 1842 & Ampeliscidae \\
\hline 19 & Ampelisca sp. B & Krøyer, 1842 & Ampeliscidae \\
\hline 20 & Ampelisca uncinata & Chevreux, 1887 & Ampeliscidae \\
\hline 21 & Amphilochoides boecki & G.O. Sars, 1892 & Amphilochidae \\
\hline 22 & Amphilochoides serratipes & (Norman, 1869) & Amphilochidae \\
\hline 23 & Amphilochus anoculus & Tandberg \& Vader, 2018 & Amphilochidae \\
\hline 24 & Amphilochus hamatus & (Stephensen, 1925) & Amphilochidae \\
\hline 25 & Amphilochus manudens & Spence Bate, 1862 & Amphilochidae \\
\hline 26 & Amphilochus sp. A & Spence Bate, 1862 & Amphilochidae \\
\hline 27 & Amphilochus sp. B & Spence Bate, 1862 & Amphilochidae \\
\hline 28 & Amphilochus sp. C & Spence Bate, 1862 & Amphilochidae \\
\hline 29 & Amphilochus tenuimanus & Boeck, 1871 & Amphilochidae \\
\hline 30 & Amphithopsis longicaudata & Boeck, 1861 & Calliopiidae \\
\hline 31 & Andaniella pectinata & G.O. Sars, 1883 & Stegocephalidae \\
\hline 32 & Andaniexis abyssi & (Boeck, 1871) & Stegocephalidae \\
\hline 33 & Andaniexis lupus & Berge \& Vader, 1997 & Stegocephalidae \\
\hline 34 & Andaniexis sp. A & Stebbing, 1906 & Stegocephalidae \\
\hline 35 & Andaniopsis nordlandica & (Boeck, 1871) & Stegocephalidae \\
\hline 36 & Andaniopsis pectinata & (G.O.Sars, 1883) & Stegocephalidae \\
\hline 37 & Anonyx sp. A & Krøyer, 1838 & Uristidae \\
\hline 38 & Apherusa glacialis & (Hansen, 1888) & Calliopiidae \\
\hline 39 & Apherusa sarsii & Shoemaker, 1930 & Calliopiidae \\
\hline 40 & Apherusa sp. A & Walker, 1891 & Calliopiidae \\
\hline
\end{tabular}




\begin{tabular}{|c|c|c|c|}
\hline 41 & Apherusa sp. B & Walker, 1891 & Calliopiidae \\
\hline 42 & Apherusa sp. C & Walker, 1891 & Calliopiidae \\
\hline 43 & Apherusa sp. D & Walker, 1891 & Calliopiidae \\
\hline 44 & Argissa hamatipes & (Norman, 1869) & Argissidae \\
\hline 45 & Arrhinopsis sp. A & Stappers, 1911 & Oedicerotidae \\
\hline 46 & Arrhis phyllonyx & (Sars, 1858) & Oedicerotidae \\
\hline 47 & Arrhis sp. A & Stebbing, 1906 & Oedicerotidae \\
\hline 48 & Astyra abyssi & Boeck, 1871 & Stilipedidae \\
\hline 49 & Astyra sp. A & Boeck, 1871 & Stilipedidae \\
\hline 50 & Austrosyrrhoe septentrionalis & Stephensen, 1931 & Synopiidae \\
\hline 51 & Austrosyrrhoe sp. A & K.H. Barnard, 1925 & Synopiidae \\
\hline 52 & Autonoe borealis & (Myers, 1976) & Aoridae \\
\hline 53 & Bathymedon longimanus & (Boeck, 1871) & Oedicerotidae \\
\hline 54 & Bathymedon obtusifrons & (Hansen, 1883) & Oedicerotidae \\
\hline 55 & Bathymedon saussurei & (Boeck, 1871) & Oedicerotidae \\
\hline 56 & Bathymedon sp. A & G.O. Sars, 1892 & Oedicerotidae \\
\hline 57 & Bruzelia sp. A & Boeck, 1871 & Synopiidae \\
\hline 58 & Bruzelia tuberculata & G.O. Sars, 1883 & Synopiidae \\
\hline 59 & Byblis crassicornis & Metzger, 1875 & Ampeliscidae \\
\hline 60 & Byblis erythrops & G.O. Sars, 1883 & Ampeliscidae \\
\hline 61 & Byblis gaimardii & (Krøyer, 1846) & Ampeliscidae \\
\hline 62 & Byblis medialis & Mills, 1971 & Ampeliscidae \\
\hline 63 & Byblis minuticornis & Sars, 1879 & Ampeliscidae \\
\hline 64 & Byblis sp. A & Boeck, 1871 & Ampeliscidae \\
\hline 65 & Byblisoides bellansantiniae & Peart, 2018 & Ampeliscidae \\
\hline 66 & Calliopius laeviusculus & (Krøyer, 1838) & Calliopiidae \\
\hline 67 & Camacho faroensis & Myers, 1998 & Aoridae \\
\hline 68 & Caprella ciliata & G.O. Sars, 1883 & Caprellidae \\
\hline 69 & Caprella dubia & Hansen, 1887 & Caprellidae \\
\hline 70 & Caprella microtuberculata & G. O. Sars, 1879 & Caprellidae \\
\hline 71 & Caprella rinki & Stephensen, 1916 & Caprellidae \\
\hline 72 & Caprella septentrionalis & Krøyer, 1838 & Caprellidae \\
\hline 73 & Chevreuxius grandimanus & Bonnier, 1896 & Aoridae \\
\hline 74 & Cleippides bicuspis & Stephensen, 1931 & Calliopiidae \\
\hline 75 & Cleippides quadricuspis & Heller, 1875 & Calliopiidae \\
\hline 76 & Cleippides tricuspis & (Krøyer, 1846) & Calliopiidae \\
\hline 77 & Cleonardo sp. A & Stebbing, 1888 & Eusiridae \\
\hline 78 & Cleonardopsis sp. A & K.H. Barnard, 1916 & Amathillopsidae \\
\hline 79 & Corophiidira sp. A & $\begin{array}{l}\text { Leach, } 1814 \text { (sensu Lowry \& } \\
\text { Myers, 2013) }\end{array}$ & Corophiidira \\
\hline 80 & Cressa carinata & Stephensen, 1931 & Cressidae \\
\hline 81 & Cressa jeanjusti & Krapp-Schickel, 2005 & Cressidae \\
\hline
\end{tabular}




\begin{tabular}{|c|c|c|c|}
\hline 82 & Cressa minuta & Boeck, 1871 & Cressidae \\
\hline 83 & Cressa quinquedentata & Stephensen, 1931 & Cressidae \\
\hline 84 & Cressina monocuspis & Stephensen, 1931 & Cressidae \\
\hline 85 & Deflexilodes norvegicus & (Boeck, 1871) & Oedicerotidae \\
\hline 86 & Deflexilodes rostratus & (Stephensen, 1931) & Oedicerotidae \\
\hline 87 & Deflexilodes subnudus & (Norman, 1889) & Oedicerotidae \\
\hline 88 & Deflexilodes tenuirostratus & (Boeck, 1871) & Oedicerotidae \\
\hline 89 & Deflexilodes tesselatus & (Schneider, 1883) & Oedicerotidae \\
\hline 90 & Deflexilodes tuberculatus & (Boeck, 1871) & Oedicerotidae \\
\hline 91 & Dulichia sp. A & Krøyer, 1845 & Dulichiidae \\
\hline 92 & Dulichia spinosissima & Krøyer, 1845 & Dulichiidae \\
\hline 93 & Dulichiopsis sp. A & Laubitz, 1977 & Dulichiidae \\
\hline 94 & Dyopedos porrectus & Spence Bate, 1857 & Dulichiidae \\
\hline 95 & Dyopedos sp. A & Spence Bate, 1857 & Dulichiidae \\
\hline 96 & Epimeria (Epimeria) loricata & G.O. Sars, 1879 & Epimeriidae \\
\hline 97 & Epimeria (Epimeria) sp. A & Costa in Hope, 1851 & Epimeriidae \\
\hline 98 & Ericthonius megalops & (Sars G.O., 1879) & Ischyroceridae \\
\hline 99 & Eusirella elegans & Chevreux, 1908 & Eusiridae \\
\hline 100 & Eusirogenes sp. A & Stebbing, 1904 & Eusiridae \\
\hline 101 & Eusirogenes sp. B & Stebbing, 1904 & Eusiridae \\
\hline 102 & Eusirus bathybius & Schellenberg, 1955 & Eusiridae \\
\hline 103 & Eusirus biscayensis & Bonnier, 1896 & Eusiridae \\
\hline 104 & Eusirus holmii & Hansen, 1887 & Eusiridae \\
\hline 105 & Eusirus longipes & Boeck, 1861 & Eusiridae \\
\hline 106 & Eusirus minutus & G.O. Sars, 1893 & Eusiridae \\
\hline 107 & Eusirus propinquus & Sars, 1893 & Eusiridae \\
\hline 108 & Eusirus sp. A & Krøyer, 1845 & Eusiridae \\
\hline 109 & Eusirus sp. B & Krøyer, 1845 & Eusiridae \\
\hline 110 & Eusirus sp. C & Krøyer, 1845 & Eusiridae \\
\hline 111 & Eusirus sp. D & Krøyer, 1845 & Eusiridae \\
\hline 112 & Eusyrophoxus sp. A & Gurjanova, 1977 & Phoxocephalidae \\
\hline 113 & Gammaropsis sp. A & Lilljeborg, 1855 & Photidae \\
\hline 114 & Gitana abyssicola & G.O. Sars, 1892 & Amphilochidae \\
\hline 115 & Gitana rostrata & Boeck, 1871 & Amphilochidae \\
\hline 116 & Gitana sarsi & Boeck, 1871 & Amphilochidae \\
\hline 117 & Gitana sp. A & Boeck, 1871 & Amphilochidae \\
\hline 118 & Gitanopsis arctica & G.O. Sars, 1892 & Amphilochidae \\
\hline 119 & Gitanopsis bispinosa & (Boeck, 1871) & Amphilochidae \\
\hline 120 & Gitanopsis inermis & (G.O.Sars, 1883) & Amphilochidae \\
\hline 121 & Gitanopsis sp. A & G.O. Sars, 1892 & Amphilochidae \\
\hline 122 & Glorandaniotes eilae & (Berge \& Vader, 1997) & Stegocephalidae \\
\hline
\end{tabular}




\begin{tabular}{|c|c|c|c|}
\hline 123 & Gronella groenlandica & (Hansen, 1888) & Tryphosidae \\
\hline 124 & Halice abyssi & Boeck, 1871 & Pardaliscidae \\
\hline 125 & Halice sp. A & Boeck, 1871 & Pardaliscidae \\
\hline 126 & Halicoides sp. A & Walker, 1896 & Pardaliscidae \\
\hline 127 & Halicoides tertia & (Stephensen, 1931) & Pardaliscidae \\
\hline 128 & Halirages fulvocinctus & (M. Sars, 1858) & Calliopiidae \\
\hline 129 & Halirages qvadridentatus & G.O. Sars, 1877 & Calliopiidae \\
\hline 130 & Halirages sp. A & Boeck, 1871 & Calliopiidae \\
\hline 131 & Haliragoides inermis & (G.O. Sars, 1883) & Calliopiidae \\
\hline 132 & Haploops carinata & Liljeborg, 1856 & Ampeliscidae \\
\hline 133 & Haploops dauvini & Peart, 2018 & Ampeliscidae \\
\hline 134 & Haploops islandica & $\begin{array}{l}\text { Kaïm-Malka, Bellan-Santini \& } \\
\text { Dauvin, } 2016\end{array}$ & Ampeliscidae \\
\hline 135 & Haploops kaimmalkai & Peart, 2018 & Ampeliscidae \\
\hline 136 & Haploops setosa & Boeck, 1871 & Ampeliscidae \\
\hline 137 & Haploops similis & Stephensen, 1925 & Ampeliscidae \\
\hline 138 & Haploops sp. A & Liljeborg, 1856 & Ampeliscidae \\
\hline 139 & Haploops tenuis & Kanneworff, 1966 & Ampeliscidae \\
\hline 140 & Haploops tubicola & Liljeborg, 1856 & Ampeliscidae \\
\hline 141 & Hardametopa nasuta & (Boeck, 1871) & Stenothoidae \\
\hline 142 & Harpinia abyssi & G.O. Sars, 1879 & Phoxocephalidae \\
\hline 143 & Harpinia antennaria & Meinert, 1890 & Phoxocephalidae \\
\hline 144 & Harpinia crenulata & (Boeck, 1871) & Phoxocephalidae \\
\hline 145 & Harpinia crenuloides & Stephensen, 1925 & Phoxocephalidae \\
\hline 146 & Harpinia laevis & Sars, 1891 & Phoxocephalidae \\
\hline 147 & Harpinia mucronata & G. O. Sars, 1879 & Phoxocephalidae \\
\hline 148 & Harpinia pectinata & Sars, 1891 & Phoxocephalidae \\
\hline 149 & Harpinia propinqua & Sars, 1891 & Phoxocephalidae \\
\hline 150 & Harpinia sp. A & Boeck, 1876 & Phoxocephalidae \\
\hline 151 & Harpinia sp. B & Boeck, 1876 & Phoxocephalidae \\
\hline 152 & Harpinia sp. C & Boeck, 1876 & Phoxocephalidae \\
\hline 153 & Harpinia sp. D & Boeck, 1876 & Phoxocephalidae \\
\hline 154 & Harpinia sp. E & Boeck, 1876 & Phoxocephalidae \\
\hline 155 & Harpinia sp. F & Boeck, 1876 & Phoxocephalidae \\
\hline 156 & Harpinia sp. G & Boeck, 1876 & Phoxocephalidae \\
\hline 157 & Harpinia sp. $\mathrm{H}$ & Boeck, 1876 & Phoxocephalidae \\
\hline 158 & Harpinia truncata & Sars, 1891 & Phoxocephalidae \\
\hline 159 & Harpiniopsis similis & Stephensen, 1925 & Phoxocephalidae \\
\hline 160 & Hippomedon gorbunovi & Gurjanova, 1929 & Tryphosidae \\
\hline 161 & Hippomedon propinqvus & G.O. Sars, 1890 & Tryphosidae \\
\hline 162 & Idunella aeqvicornis & (G.O. Sars, 1877) & Liljeborgiidae \\
\hline 163 & Idunella sp. A & G.O. Sars, 1894 & Liljeborgiidae \\
\hline
\end{tabular}




\begin{tabular}{|c|c|c|c|}
\hline 164 & Ischyrocerus anguipes & Krøyer, 1838 & Ischyroceridae \\
\hline 165 & Ischyrocerus latipes & Krøyer, 1842 & Ischyroceridae \\
\hline 166 & Ischyrocerus megacheir & (Boeck, 1871) & Ischyroceridae \\
\hline 167 & Ischyrocerus megalops & Sars, 1894 & Ischyroceridae \\
\hline 168 & Jassa sp. A & Leach, 1814 & Ischyroceridae \\
\hline 169 & Kerguelenia borealis & G.O. Sars, 1891 & Kergueleniidae \\
\hline 170 & Laetmatophilus sp. A & Bruzelius, 1859 & Podoceridae \\
\hline 171 & Laetmatophilus tuberculatus & Bruzelius, 1859 & Podoceridae \\
\hline 172 & Laothoes meinerti & Boeck, 1871 & Calliopiidae \\
\hline 173 & Laothoes pallaschi & Coleman, 1999 & Calliopiidae \\
\hline 174 & Laothoes sp. A & Boeck, 1871 & Calliopiidae \\
\hline 175 & Lepechinella arctica & Schellenberg, 1926 & Lepechinellidae \\
\hline 176 & Lepechinella grimi & Thurston, 1980 & Lepechinellidae \\
\hline 177 & Lepechinella helgii & Thurston, 1980 & Lepechinellidae \\
\hline 178 & Lepechinella skarphedini & Thurston, 1980 & Lepechinellidae \\
\hline 179 & Lepechinella victoriae & Johansen \& Vader, 2015 & Lepechinellidae \\
\hline 180 & Lepechinelloides karii & Thurston, 1980 & Lepechinellidae \\
\hline 181 & Lepidepecreum sp. A & Spence Bate \& Westwood, 1868 & Tryphosidae \\
\hline 182 & Leptamphopus sarsi & Vanhöffen, 1897 & Calliopiidae \\
\hline 183 & Leptophoxus falcatus & (G.O.Sars, 1883) & Phoxocephalidae \\
\hline 184 & Leucothoe lilljeborgi & Boeck, 1861 & Leucothoidae \\
\hline 185 & Leucothoe sp. A & Leach, 1814 & Leucothoidae \\
\hline 186 & Leucothoe spinicarpa & (Abildgaard, 1789) & Leucothoidae \\
\hline 187 & Leucothoe vaderotti & Krapp-Schickel, 2018 & Leucothoidae \\
\hline 188 & Liljeborgia fissicornis & (Sars, 1858) & Liljeborgiidae \\
\hline 189 & Liljeborgia pallida & (Spence Bate, 1857) & Liljeborgiidae \\
\hline 190 & Liljeborgia sp. A & Spence Bate, 1862 & Liljeborgiidae \\
\hline 191 & Lysianella petalocera & G.O. Sars, 1883 & Tryphosidae \\
\hline 192 & Megamoera dentata & (Krøyer, 1842) & Melitidae \\
\hline 193 & Megamphopus raptor & Myers, 1998 & Photidae \\
\hline 194 & Melphidippa borealis & Boeck, 1871 & Melphidippidae \\
\hline 195 & Melphidippa goesi & Stebbing, 1899 & Melphidippidae \\
\hline 196 & Melphidippa macrura & G.O. Sars, 1894 & Melphidippidae \\
\hline 197 & Melphidippa sp. A & Boeck, 1871 & Melphidippidae \\
\hline 198 & Melphidippa sp. B & Boeck, 1871 & Melphidippidae \\
\hline 199 & Metacaprella horrida & (Sars G.O., 1877) & Caprellidae \\
\hline 200 & Metandania wimi & Berge, 2001 & Stegocephalidae \\
\hline 201 & Metopa abyssalis & Stephensen, 1931 & Stenothoidae \\
\hline 202 & Metopa boeckii & Sars, 1892 & Stenothoidae \\
\hline 203 & Metopa bruzelii & (Goës, 1866) & Stenothoidae \\
\hline 204 & Metopa leptocarpa & G.O. Sars, 1883 & Stenothoidae \\
\hline
\end{tabular}




\begin{tabular}{|c|c|c|c|}
\hline 205 & Metopa norvegica & (Liljeborg, 1851) & Stenothoidae \\
\hline 206 & Metopa palmata & Sars, 1892 & Stenothoidae \\
\hline 207 & Metopa robusta & Sars, 1892 & Stenothoidae \\
\hline 208 & Metopa rubrovittata & G.O. Sars, 1883 & Stenothoidae \\
\hline 209 & Metopa sinuata & Sars, 1892 & Stenothoidae \\
\hline 210 & Metopa sp. A & Boeck, 1871 & Stenothoidae \\
\hline 211 & Metopa sp. B & Boeck, 1871 & Stenothoidae \\
\hline 212 & Metopa sp. C & Boeck, 1871 & Stenothoidae \\
\hline 213 & Metopa sp. D & Boeck, 1871 & Stenothoidae \\
\hline 214 & Metopa sp. E & Boeck, 1871 & Stenothoidae \\
\hline 215 & Monoculodes latimanus & (Goës, 1866) & Oedicerotidae \\
\hline 216 & Monoculodes latissimanus & Stephensen, 1931 & Oedicerotidae \\
\hline 217 & Monoculodes packardi & Boeck, 1871 & Oedicerotidae \\
\hline 218 & Monoculodes sp. A & Stimpson, 1853 & Oedicerotidae \\
\hline 219 & Monoculodes sp. B & Stimpson, 1853 & Oedicerotidae \\
\hline 220 & Monoculodes sp. C & Stimpson, 1853 & Oedicerotidae \\
\hline 221 & Monoculodes sp. D & Stimpson, 1853 & Oedicerotidae \\
\hline 222 & Monoculodes sp. E & Stimpson, 1853 & Oedicerotidae \\
\hline 223 & Monoculodes sp. F & Stimpson, 1853 & Oedicerotidae \\
\hline 224 & Monoculodes sp. G & Stimpson, 1853 & Oedicerotidae \\
\hline 225 & Monoculopsis longicornis & (Boeck, 1871) & Oedicerotidae \\
\hline 226 & Neopleustes boecki & (Hansen, 1888) & Pleustidae \\
\hline 227 & Neopleustes pulchellus & (Krøyer, 1846) & Pleustidae \\
\hline 228 & Neopleustes sp. A & Stebbing, 1906 & Pleustidae \\
\hline 229 & Nicippe tumida & Bruzelius, 1859 & Pardaliscidae \\
\hline 230 & Nototropis smitti & (Goës, 1866) & Atylidae \\
\hline 231 & Nototropis sp. A & Costa, 1853 & Atylidae \\
\hline 232 & Odius carinatus & (Spence Bate, 1862) & Ochlesidae \\
\hline 233 & Oedicerina ingolfi & Stephensen, 1931 & Oedicerotidae \\
\hline 234 & Oedicerina sp. A & Stephensen, 1931 & Oedicerotidae \\
\hline 235 & Oediceropsis brevicornis & Lilljeborg, 1865 & Oedicerotidae \\
\hline 236 & Oediceropsis sp. A & Lilljeborg, 1865 & Oedicerotidae \\
\hline 237 & Oediceros borealis & Boeck, 1871 & Oedicerotidae \\
\hline 238 & Onisimus plautus & (Krøyer, 1845) & Uristidae \\
\hline 239 & Orchomene macroserratus & Shoemaker, 1930 & Tryphosidae \\
\hline 240 & Orchomene pectinatus & G.O. Sars, 1883 & Tryphosidae \\
\hline 241 & Orchomene sp. A & Boeck, 1871 & Tryphosidae \\
\hline 242 & Pacifoculodes pallidus & (G.O. Sars, 1892) & Oedicerotidae \\
\hline 243 & Paradulichia typica & Boeck, 1871 & Dulichiidae \\
\hline 244 & Paramphilochoides odontonyx & (Boeck, 1871) & Amphilochidae \\
\hline 245 & Paramphithoe hystrix & (Ross, 1835) & Paramphithoidae \\
\hline
\end{tabular}




\begin{tabular}{|c|c|c|c|}
\hline 246 & Parandania gigantea & (Stebbing, 1883) & Stegocephalidae \\
\hline 247 & Paraphoxus oculatus & (G. O. Sars, 1879) & Phoxocephalidae \\
\hline 248 & Parapleustes assimilis & (G.O. Sars, 1883) & Pleustidae \\
\hline 249 & Parapleustes bicuspis & (Krøyer, 1838) & Pleustidae \\
\hline 250 & Pardalisca abyssi & Boeck, 1871 & Pardaliscidae \\
\hline 251 & Pardalisca cuspidata & Krøyer, 1842 & Pardaliscidae \\
\hline 252 & Pardalisca sp. A & Krøyer, 1842 & Pardaliscidae \\
\hline 253 & Pardalisca sp. B & Krøyer, 1842 & Pardaliscidae \\
\hline 254 & Pardalisca sp. C & Krøyer, 1842 & Pardaliscidae \\
\hline 255 & Pardalisca tenuipes & G.O. Sars, 1893 & Pardaliscidae \\
\hline 256 & Pardaliscoides tenellus & Stebbing, 1888 & Pardaliscidae \\
\hline 257 & Paroediceros curvirostris & (Hansen, 1888) & Oedicerotidae \\
\hline 258 & Paroediceros lynceus & (M. Sars, 1858) & Oedicerotidae \\
\hline 259 & Paroediceros propinquus & (Goës, 1866) & Oedicerotidae \\
\hline 260 & Perioculodes longimanus & (Spence Bate \& Westwood, 1868) & Oedicerotidae \\
\hline 261 & Phippsia gibbosa & (G.O. Sars, 1883) & Stegocephalidae \\
\hline 262 & Phippsia roemeri & Schellenberg, 1925 & Stegocephalidae \\
\hline 263 & Photis reinhardi & Krøyer, 1842 & Photidae \\
\hline 264 & Phoxocephalus holbolli & (Krøyer, 1842) & Phoxocephalidae \\
\hline 265 & Pleustes (Pleustes) panoplus & (Krøyer, 1838) & Pleustidae \\
\hline 266 & Pleustes tuberculatus & Spence Bate, 1858 & Pleustidae \\
\hline 267 & Pleusymtes pulchella & (G.O. Sars, 1876) & Pleustidae \\
\hline 268 & Pleusymtes sp. A & J.L. Barnard, 1969 & Pleustidae \\
\hline 269 & Pontocrates arcticus & G.O. Sars, 1895 & Oedicerotidae \\
\hline 270 & Pontocrates sp. A & Boeck, 1871 & Oedicerotidae \\
\hline 271 & Proaeginina norvegica & (Stephensen, 1931) & Caprellidae \\
\hline 272 & Proboloides gregaria & (G.O. Sars, 1883) & Stenothoidae \\
\hline 273 & Protellina ingolfi & Stephensen, 1944 & Caprellidae \\
\hline 274 & Protoaeginella muriculata & Laubitz \& Mills, 1972 & Caprellidae \\
\hline 275 & Protomedeia fasciata & Krøyer, 1842 & Corophiidae \\
\hline 276 & Pseudo bioice & (Berge \& Vader, 1997) & Stegocephalidae \\
\hline 277 & Pseudotiron sp. A & Chevreux, 1895 & Synopiidae \\
\hline 278 & Rhachotropis aculeata & (Lepechin, 1780) & Eusiridae \\
\hline 279 & Rhachotropis arii & Thurston, 1980 & Eusiridae \\
\hline 280 & Rhachotropis distincta & (Holmes, 1908) & Eusiridae \\
\hline 281 & Rhachotropis gislii & Thurston, 1980 & Eusiridae \\
\hline 282 & Rhachotropis gloriosae & Ledoyer, 1982 & Eusiridae \\
\hline 283 & Rhachotropis helleri & (Boeck, 1871) & Eusiridae \\
\hline 284 & Rhachotropis inflata & (G.O. Sars, 1883) & Eusiridae \\
\hline 285 & Rhachotropis kergueleni & Stebbing, 1888 & Eusiridae \\
\hline 286 & Rhachotropis leucophthalma & G.O. Sars, 1893 & Eusiridae \\
\hline
\end{tabular}




\begin{tabular}{|c|c|c|c|}
\hline 287 & Rhachotropis macropus & G.O. Sars, 1893 & Eusiridae \\
\hline 288 & Rhachotropis northriana & $\begin{array}{l}\text { d'Udekem d'Acoz, Vader \& } \\
\text { Legezinska, } 2007\end{array}$ & Eusiridae \\
\hline 289 & Rhachotropis oculata & (Hansen, 1887) & Eusiridae \\
\hline 290 & Rhachotropis palporum & Stebbing, 1908 & Eusiridae \\
\hline 291 & Rhachotropis proxima & Chevreux, 1911 & Eusiridae \\
\hline 292 & Rhachotropis sp. A & S.I. Smith, 1883 & Eusiridae \\
\hline 293 & Rhachotropis sp. B & S.I. Smith, 1883 & Eusiridae \\
\hline 294 & Rhachotropis sp. C & S.I. Smith, 1883 & Eusiridae \\
\hline 295 & Rhachotropis sp. D & S.I. Smith, 1883 & Eusiridae \\
\hline 296 & Rhachotropis thordisae & Thurston, 1980 & Eusiridae \\
\hline 297 & Rhachotropis thorkelli & Thurston, 1980 & Eusiridae \\
\hline 298 & Rostroculodes borealis & (Boeck, 1871) & Oedicerotidae \\
\hline 299 & Rostroculodes kroyeri & (Boeck, 1870) & Oedicerotidae \\
\hline 300 & Rostroculodes longirostris & (Goës, 1866) & Oedicerotidae \\
\hline 301 & Scopelocheirus sp. A & Spence Bate, 1857 & Scopelocheiridae \\
\hline 302 & Sicafodia iceage & Campean \& Coleman, 2017 & Sicafodiidae \\
\hline 303 & Sicafodia sp. A & Just, 2004 & Sicafodiidae \\
\hline 304 & Siphonoecetes typicus & Krøyer, 1845 & Ischyroceridae \\
\hline 305 & Socarnes bidenticulatus & (Spence Bate, 1858) & Lysianassidae \\
\hline 306 & Socarnes vahlii & (Krøyer, 1838) & Lysianassidae \\
\hline 307 & Stegocephalina wagini & (Gurjanova, 1936) & Stegocephalidae \\
\hline 308 & Stegocephaloides auratus & (G.O. Sars, 1883) & Stegocephalidae \\
\hline 309 & Stegocephaloides barnardi & Berge \& Vader, 1997 & Stegocephalidae \\
\hline 310 & $\begin{array}{l}\text { Stegocephaloides } \\
\text { christianiensis }\end{array}$ & Boeck, 1871 & Stegocephalidae \\
\hline 311 & Stegocephalus ampulla & (Phipps, 1774) & Stegocephalidae \\
\hline 312 & Stegocephalus inflatus & Krøyer, 1842 & Stegocephalidae \\
\hline 313 & Stegocephalus similis & Sars, 1891 & Stegocephalidae \\
\hline 314 & Stegocephalus sp. A & Krøyer, 1842 & Stegocephalidae \\
\hline 315 & Stegocephalus sp. B & Krøyer, 1842 & Stegocephalidae \\
\hline 316 & Stegonomadia biofar & (Berge \& Vader, 1997) & Stegocephalidae \\
\hline 317 & Stegonomadia idae & (Berge \& Vader, 1997) & Stegocephalidae \\
\hline 318 & Stegoplax longirostris & G.O. Sars, 1883 & Cyproideidae \\
\hline 319 & Stegoplax sp. A & G.O. Sars, 1883 & Cyproideidae \\
\hline 320 & Stenopleustes latipes & (M. Sars, 1858) & Pleustidae \\
\hline 321 & Stenopleustes malmgreni & (Boeck, 1871) & Pleustidae \\
\hline 322 & Stenopleustes nodifera & (G.O.Sars, 1883) & Pleustidae \\
\hline 323 & Stenopleustes sp. A & G.O. Sars, 1893 & Pleustidae \\
\hline 324 & Stenothoe marina & (Spence Bate, 1857) & Stenothoidae \\
\hline 325 & Stenothoe megacheir & (Boeck, 1871) & Stenothoidae \\
\hline 326 & Stenothoe sp. A & Dana, 1852 & Stenothoidae \\
\hline
\end{tabular}




\begin{tabular}{|c|c|c|c|}
\hline 327 & Stenothoe sp. B & Dana, 1852 & Stenothoidae \\
\hline 328 & Stenothoe sp. C & Dana, 1852 & Stenothoidae \\
\hline 329 & Stenothoe sp. D & Dana, 1852 & Stenothoidae \\
\hline 330 & Stephobruzelia dentata & (Stephensen, 1931) & Synopiidae \\
\hline 331 & Synchelidium haplocheles & (Grube, 1864) & Oedicerotidae \\
\hline 332 & Synchelidium intermedium & Sars, 1892 & Oedicerotidae \\
\hline 333 & Synchelidium sp. A & G.O. Sars, 1892 & Oedicerotidae \\
\hline 334 & Syrrhoe crenulata & Goës, 1866 & Synopiidae \\
\hline 335 & Syrrhoe sp. A & Goës, 1866 & Synopiidae \\
\hline 336 & Syrrhoites pusilla & Enequist, 1949 & Synopiidae \\
\hline 337 & Syrrhoites serrata & (G.O. Sars, 1879) & Synopiidae \\
\hline 338 & Syrrhoites sp. A & G.O. Sars, 1893 & Synopiidae \\
\hline 339 & Themisto gaudichaudii & Guérin, 1825 & Hyperiidae \\
\hline 340 & Thorina elongata & Laubitz \& Mills, 1972 & Caprellidae \\
\hline 341 & Thorina spinosa & Stephensen, 1944 & Caprellidae \\
\hline 342 & Tiron spiniferus & (Stimpson, 1853) & Synopiidae \\
\hline 343 & Tmetonyx cicada & (Fabricius, 1780) & Uristidae \\
\hline 344 & Tmetonyx sp. A & Stebbing, 1906 & Uristidae \\
\hline 345 & Tryphosella schneideri & (Stephensen, 1921) & Tryphosidae \\
\hline 346 & Tryphosella sp. A & Bonnier, 1893 & Tryphosidae \\
\hline 347 & Unciola laticornis & Hansen, 1887 & Unciolidae \\
\hline 348 & Unciola leucopis & (Krøyer, 1845) & Unciolidae \\
\hline 349 & Unciola planipes & Norman, 1867 & Unciolidae \\
\hline 350 & Urothoe elegans & Spence Bate, 1857 & Urothoidae \\
\hline 351 & Westwoodilla brevicalcar & Goës, 1866 & Oedicerotidae \\
\hline 352 & Westwoodilla caecula & (Spence Bate, 1857) & Oedicerotidae \\
\hline 353 & Westwoodilla megalops & (G.O. Sars, 1883) & Oedicerotidae \\
\hline 354 & Westwoodilla sp. A & Spence Bate, 1862 & Oedicerotidae \\
\hline 355 & Xenodice sp. A & Boeck, 1871 & Podoceridae \\
\hline
\end{tabular}




\section{Table 3 (on next page)}

Indicator Value analyses

Indicator value analysis for all combinations of the environmental clusters. The group-size corrected Indicator Value (IndVal.g) represent the association value of a species with a given cluster. The $p$-value is based on 999 permutations. 
1 Table 3. Indicator value analysis for all combinations of the environmental clusters. The group-size 2 corrected Indicator Value (IndVal.g) represent the association value of a species with a given cluster. The 3 -value is based on 999 permutations.

\begin{tabular}{|c|c|c|c|c|c|}
\hline Cluster & Nr. & Species & IndVal.g & p-value & \\
\hline \multirow{10}{*}{ Coastal } & 1 & Rhachotropis oculata & 0.400 & 0.005 & $* *$ \\
\hline & 2 & Westwoodilla caecula & 0.383 & 0.015 & $*$ \\
\hline & 3 & Ampelisca macrocephala & 0.368 & 0.010 & $* *$ \\
\hline & 4 & Deflexilodes tesselatus & 0.368 & 0.035 & $*$ \\
\hline & 5 & Harpinia sp. 5 & 0.343 & 0.020 & $*$ \\
\hline & 6 & Monoculodes sp.A & 0.343 & 0.015 & $*$ \\
\hline & 7 & Westwoodilla megalops & 0.343 & 0.030 & $*$ \\
\hline & 8 & Harpinia pectinata & 0.328 & 0.020 & $*$ \\
\hline & 9 & Bathymedon obtusifrons & 0.319 & 0.035 & $*$ \\
\hline & 10 & Monoculodes latimanus & 0.297 & 0.045 & $*$ \\
\hline \multirow{8}{*}{ Deep North } & 1 & Cleippides quadricuspis & 0.642 & 0.005 & $* *$ \\
\hline & 2 & Bruzelia dentata & 0.463 & 0.005 & $* *$ \\
\hline & 3 & Rhachotropis sp A & 0.392 & 0.005 & $* *$ \\
\hline & 4 & Paroediceros curvirostris & 0.375 & 0.015 & $*$ \\
\hline & 5 & Deflexilodes tenuirostratus & 0.349 & 0.040 & $*$ \\
\hline & 6 & Halirages quadridentata & 0.344 & 0.025 & $*$ \\
\hline & 7 & Monoculopsis longicornis & 0.344 & 0.025 & $*$ \\
\hline & 8 & Oedicerina sp & 0.327 & 0.025 & $*$ \\
\hline \multirow{17}{*}{ Deep South } & 1 & Rhachotropis thordisae & 0.559 & 0.005 & $* *$ \\
\hline & 2 & Rhachotropis proxima & 0.499 & 0.010 & $* *$ \\
\hline & 3 & Eusirus bathybius & 0.459 & 0.010 & $* *$ \\
\hline & 4 & Lepechinelloides karii & 0.459 & 0.005 & $* *$ \\
\hline & 5 & Rhachotropis gislii & 0.459 & 0.005 & $* *$ \\
\hline & 6 & Protoaeginella muriculata & 0.401 & 0.010 & $* *$ \\
\hline & 7 & Cleonardopsis sp & 0.397 & 0.005 & $* *$ \\
\hline & 8 & Lepechinella grimi & 0.397 & 0.005 & $* *$ \\
\hline & 9 & Lepechinella helgii & 0.397 & 0.010 & $* *$ \\
\hline & 10 & Lepechinella skarphedini & 0.397 & 0.010 & $* *$ \\
\hline & 11 & Rhachotropis thorkelli & 0.397 & 0.010 & $* *$ \\
\hline & 12 & Neopleustes boecki & 0.365 & 0.010 & $* *$ \\
\hline & 13 & Neopleustes sp & 0.324 & 0.010 & $* *$ \\
\hline & 14 & Sicafodia sp & 0.324 & 0.010 & $* *$ \\
\hline & 15 & Eusirus sp C & 0.300 & 0.020 & $*$ \\
\hline & 16 & Rhachotropis aislii & 0.300 & 0.040 & $*$ \\
\hline & 17 & Rhachotropis gloriosae & 0.300 & 0.035 & $*$ \\
\hline \multirow{2}{*}{ GFIR } & 1 & Ampelisca odontoplax & 0.348 & 0.03 & $*$ \\
\hline & 2 & Haploops tenuis & 0.302 & 0.05 & $*$ \\
\hline \multirow{7}{*}{ Coastal + Deep North } & 1 & Eusirus holmi & 0.509 & 0.005 & $* *$ \\
\hline & 2 & Halirages fulvocincta & 0.490 & 0.050 & $*$ \\
\hline & 3 & Arrhis phyllonyx & 0.458 & 0.005 & $* *$ \\
\hline & 4 & Andaniella pectinata & 0.430 & 0.005 & $* *$ \\
\hline & 5 & Paroediceros propinquus & 0.372 & 0.040 & $*$ \\
\hline & 6 & Halirages elegans & 0.359 & 0.030 & $*$ \\
\hline & 7 & Harpiniopsis similis & 0.347 & 0.035 & $*$ \\
\hline \multirow{4}{*}{ Coastal + GFIR } & 1 & Aeginella spinosa & 0.559 & 0.005 & $* *$ \\
\hline & 2 & Rhachotropis aculeata & 0.467 & 0.025 & $*$ \\
\hline & 3 & Caprella microtuberculata & 0.462 & 0.010 & $* *$ \\
\hline & 4 & Harpinia propinqua & 0.459 & 0.030 & $*$ \\
\hline \multirow{2}{*}{ Deep South + Deep North } & 1 & Liljeborgia pallida & 0.349 & 0.045 & $*$ \\
\hline & 2 & Ampelisca islandica & 0.329 & 0.025 & $*$ \\
\hline
\end{tabular}


